Primljen / Received: 25.2.2021

Ispravljen / Corrected: 20.5.2021.

Prihvaćen / Accepted: 27.5.2021.

Dostupno online / Available online: 10.6.2021.

\title{
Structural renovation of residential building in Zagreb after the 22 March 2020 earthquake
}

Authors:

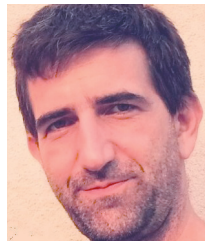

Juraj Pojatina, MCE

Studio Arhing d.o.o., Zagreb

juraj@studio-arhing.com

Corresponding author

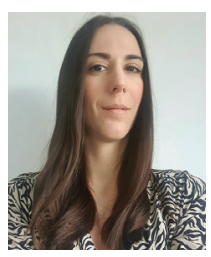

Dunja Barić, MCE

Studio Arhing d.o.o., Zagreb

dunja@studio-arhing.com

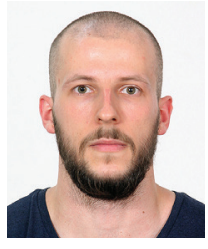

David Anđić, MCE

Studio Arhing d.o.o., Zagreb

david@studio-arhing.com

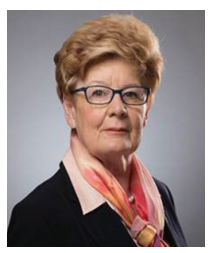

Prof.emer. Dubravka Bjegović, PhD. CE

University of Zagreb

Faculty of Civil Engineering

dubravka.bjegovic@grad.unizg.hr
Juraj Pojatina, Dunja Barić, David Anđić, Dubravka Bjegović

Professional pape

\section{Structural renovation of residential building in Zagreb after the 22 March 2020 earthquake}

The phases that must be completed so that a building damaged in earthquake that struck Zagreb on 22 March 2020 can be renovated and strengthened to the required level of seismic resistance are presented in the paper. All phases are therefore presented, starting from the rapid and then detailed inspection, and continuing with preparation of the structural condition assessment report, preparation of renovation design and, finally, ending with realisation of work with expert supervision. A special attention is paid to structural analysis that is conducted using a nonlinear static method based on displacements, the so called pushover analysis, which is considered to be one of the most appropriate methods for seismic analysis of existing masonry structures. All procedures conducted in the scope of this renovation were realised in accordance with legislation that entered into force after the earthquake.

Key words:

earthquake, renovation of building structure, strengthening, repair, pushover method

Stručni rad

Juraj Pojatina, Dunja Barić, David Anđić, Dubravka Bjegović

\section{Obnova gradevinske konstrukcije stambene zgrade u Zagrebu nakon potresa} 22. ožujka 2020.

Rad detaljno prikazuje faze koje je potrebno proći kako bi se zgrada oštećena u potresu koji je pogodio Zagreb 22. ožujka 2020. obnovila i pojačala do zahtijevane razine potresne otpornosti. Prikazane su sve faze počevši od preliminarnog pregleda pa potom i detaljnog pregleda, izrade elaborata ocjene stanja građevinske konstrukcije, projekta obnove te konačno izvođenja radova obnove uz stručni nadzor. Posebna je pozornost usmjerena na proračun građevine nelinearnom statičkom metodom koja se temelji na pomacima, tzv. "pushover analysis" ili metoda postupnog guranja, za koju se smatra da je jedna od najprimjerenijih metoda za seizmičku analizu postojećih zidanih konstrukcija. Svi postupci koji su provedeni u sklopu ove obnove su provedeni u skladu sa zakonskom regulativom koja je stupila na snagu nakon potresa.

Ključne riječi:

potres, obnova gradevinske konstrukcije, pojačanje, popravak, metoda postupnog guranja 


\section{Introduction}

The earthquake that shook Zagreb in the early morning hours of 22 March 2020 caused significant damage to numerous public and residential buildings in the city of Zagreb, especially in the Lower Town, but also in other parts of the city where buildings built in the late $19^{\text {th }}$ and early $20^{\text {th }}$ century are dominant, as presented in great detail in paper [1]. One such building is the residential building located at the address of Medveščak 160 in Zagreb, and its journey from the occurrence of damage to the full renovation of the building will be presented in this paper. The final goal was achieved by proper and fast intervention of all participants in the building process who prepared, in a relatively short time span, all required documentation and then realized all necessary structural repair and strengthening works, as presented in the diagram given in Figure 1.

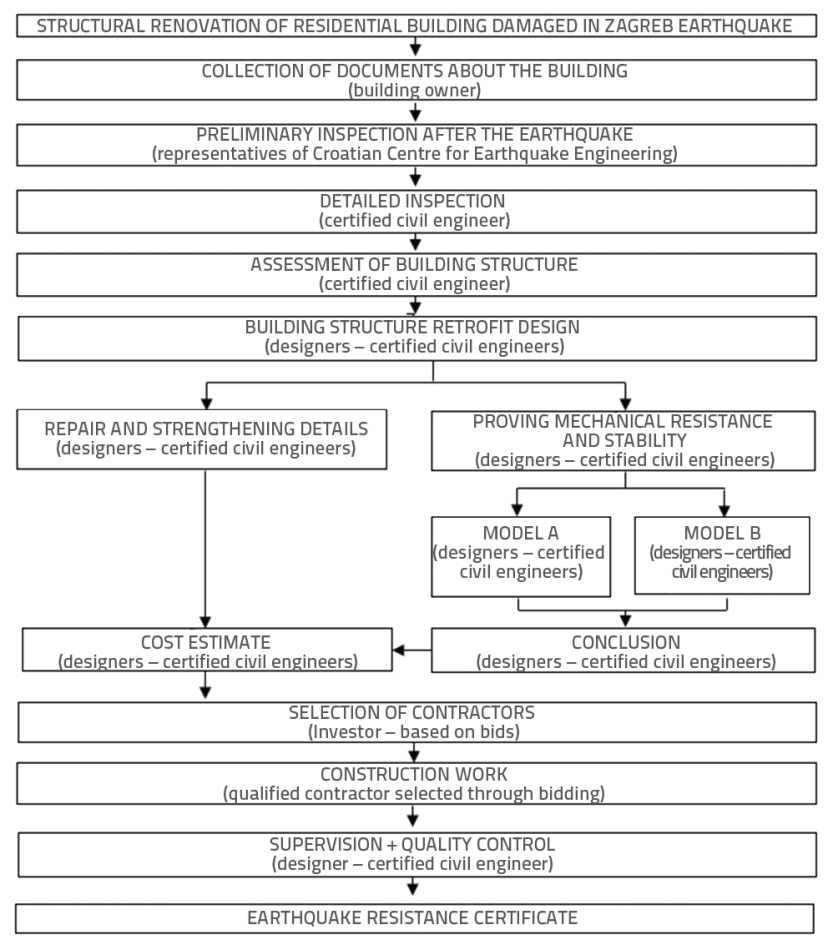

Figure 1. Diagram showing order of activities for post-earthquake structural renovation of a residential buildi

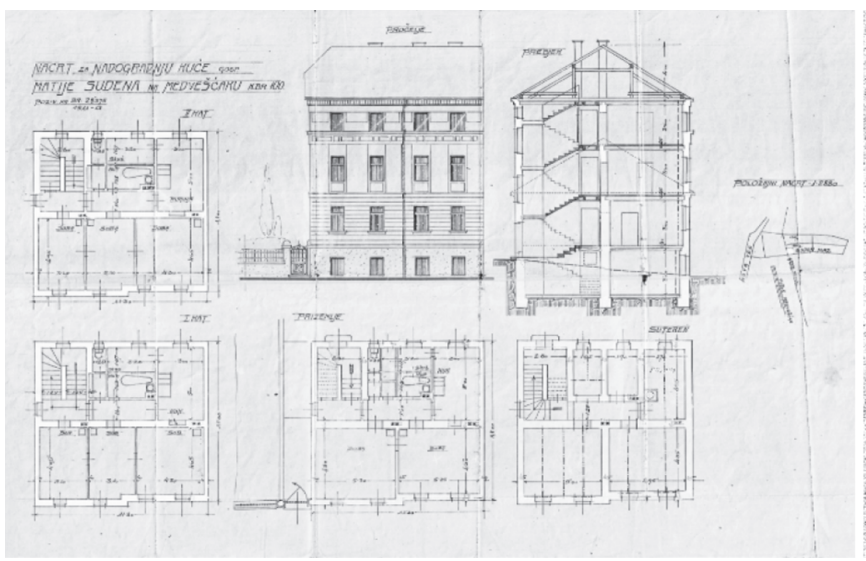

Figure 2. Building drawings from 1910 (left) and 1922 (right)

\section{Historic information about the building}

The owners of the family house at Medveščak 106 have two building drawings, as shown in Figure 2. One drawing dates back to 1910, and the other is from 1922.

According to the words of the now deceased original owner of the building, who was himself a builder by profession, the building was initially built as a single-storey house and was used by the owners as a vacation home. In the early 1920s, a building addition was realised as shown on the drawings in Figure 2 (right). These drawings were used as basis for procurement of the construction permit No. 45025, which was issued on 18 August 1922. Subsequently, the use permit was issued based on the building inspection report issued by relevant inspection team on 7 November 1922. According to both drawings, the building is a masonry structure with longitudinal load bearing facade walls, and with a central load bearing wall, all of them $50 \mathrm{~cm}$ in thickness. The main facades, shown in Figure 2, are oriented as follows: the street facing facade is oriented toward the west, and the yard facing facade - where the building's entrance is situated - is oriented toward the east. Load bearing walls provide support for wooden ceiling wooden ceiling beams, except for the ceiling structure of the lower ground floor, where steel I-sections are used. Distance between load bearing walls is $5 \mathrm{~m}$. Solid bricks measuring $25 \times 12 \mathrm{x}$ $6.5 \mathrm{~cm}$, laid probably in lime mortar, were used. Joints in two layers do not overlap, but are spaced between one quarter and/or one half of the brick. Bricks were laid in layers according to brick-laying rules so that, on longitudinal walls, bricks were laid on their long side. At the corners of the building, bricks were bonded using the alternating bond without columns or vertical tie columns.

The west side facade was renovated in the 1950s, i.e. Hirofa plaster was applied using the mason's hand placing technique. On the north and east facade walls, wall surface was improved in the 1990s by removing the old plaster all the way to the brick, and by cleaning the joints $2-3 \mathrm{~cm}$ in depth. The first plaster layer was applied by hand to make sure that the plaster penetrates into the joints. The present day appearance of the building facade, shown in Figure 3, does not fully correspond to the original drawings as some minor alterations, mostly involving pargeting, were made in the course of time.

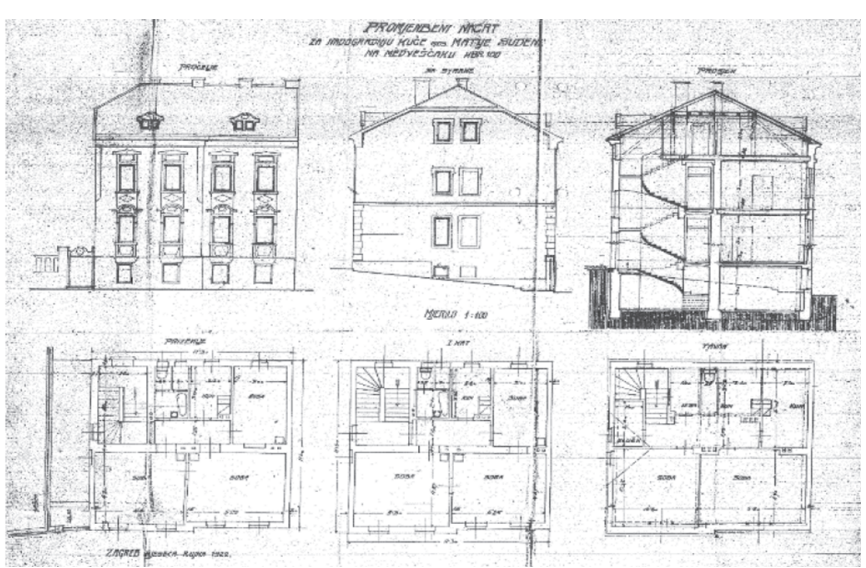



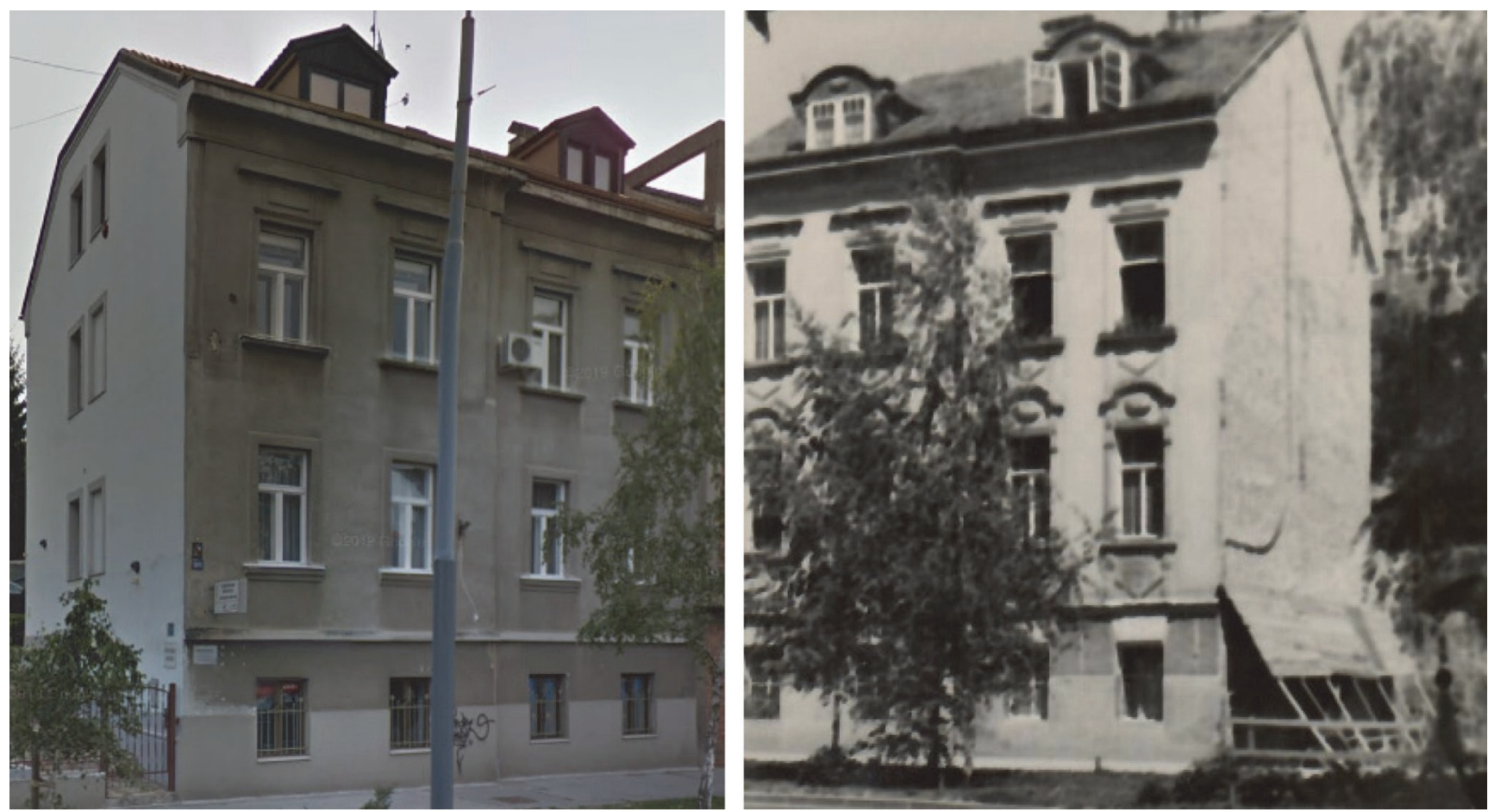

Figure 3. View of the family house (photo taken in 2020 , left) and from the first half of the $20^{\text {th }}$ century when the adjoining house was not yet built (right)

\section{Preliminary and detailed inspection of the building}

After the 22 March earthquake and rapid organisation of the Croatian Centre for Earthquake Engineering, this building was inspected by civil engineering experts in the scope of
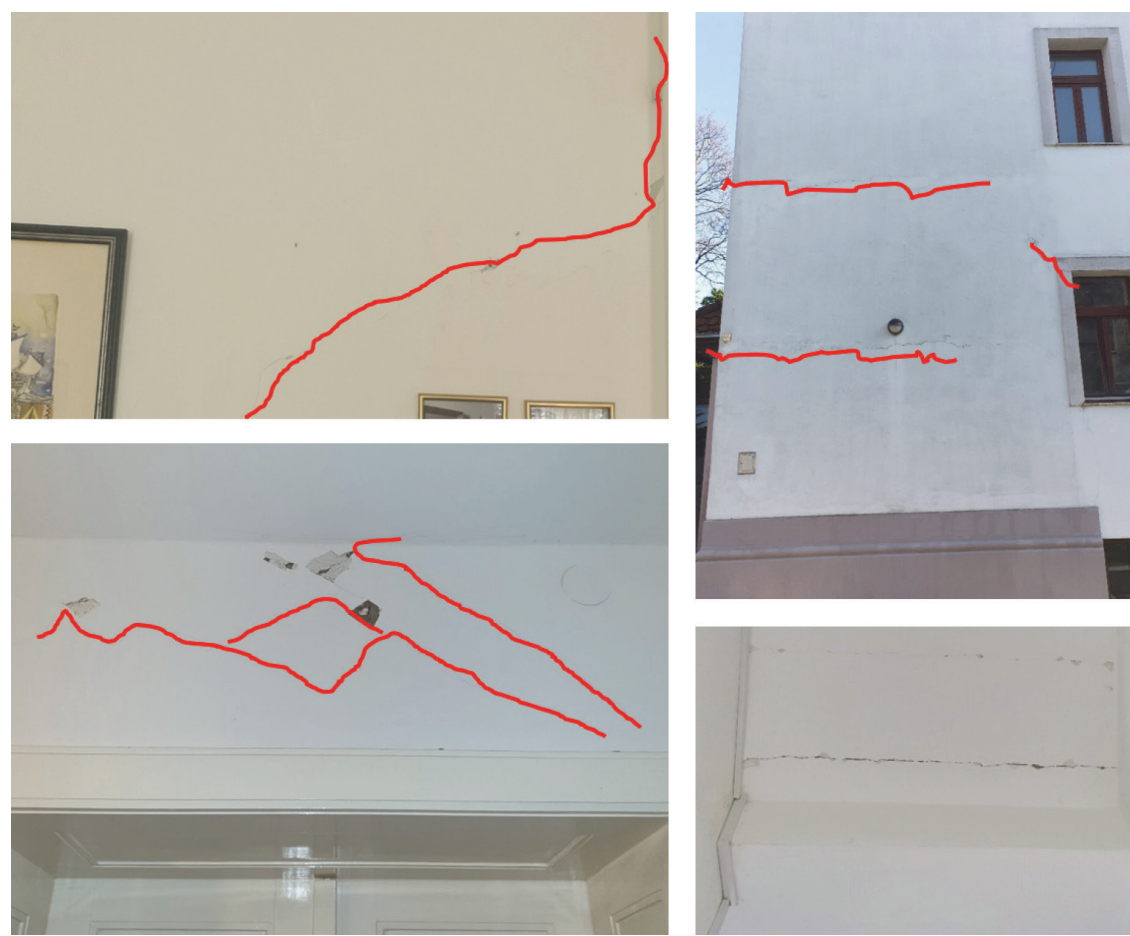

Figure 4. Typical damage to load bearing structure preliminary (rapid) inspection that included building damage and serviceability assessment. After this inspection, green label was assigned to the building which means that the building is fit for purpose utile.

A detailed visual inspection of the entire building was conducted soon after the above mentioned rapid inspection. This detailed inspection included inspection of all load bearing walls, inspection of ceilings and facades and inspection of all other non-structural elements of the building. Photographic documentation of the inspected building was also made, where all damage observed during inspections was properly marked. Geometry of all building elements was measured as basis for making drawings of the existing structure ??.. After the detailed inspection it was established that, althoug $\mathrm{h}$ the green lable was initially assigned to the building, the building did summer significant damage that was observed only after smaller investigations works such as those involving removal of plaster from some parts of the building, removal of some parts of the ceiling, etc. Some cases of typical damage are shown in Figure 4. Diagonal cracks at the load bearing ball, which transforms into a vertical crack at the connection with a partition wall, can be seen in Figure 4 (top left). Diagonal cracks 
at the lintel of the central load bearing wall can be seen in the same figure (bottom left). Cracks at the nort facade are visible at the top right protion of the figure, while cracks at the staircase ceiling can be observed at the bottom right part of the figure.

\section{Structural condition assessment report}

After the detailed inspection, the next step was to prepare the structural condition assessment report and so this report was prepared based on the data collected during the detailed inspection. The report contains general information about the building, and assessment of building structure. It also includes appropriate drawings and spatial model of the structure showing positions of damage, which is further documented with photographs. Figure 5 shows the spatial model of the building, prepared using the Tower 8.3 software [2], and a typical wall on which damage positions are marked. Most damage involves vertical, horizontal and diagonal cracks at external sides of the north and east facade walls, mostly at the ground floor and at the first floor, and significant cracks at lintels of the central load bearing wall. Damage was also incurred at the staircase, where cracks can be observed at the staircase ceiling, while net cracks can also be seen at the central staircase wall. No structural damage was observed at the lower ground floor level. The inspection of the wooden roof structure did not reveal any damage, and so mechanical resistance and stability of this structure is considered satisfactory. The report also contains a preliminary analysis of seismic resistance of the building so that it can be estimated to what extent the building meets current regulations and standards, and in order to determine whether the building is suitable for renovation and structural strengthening. After preliminary analyses, it was concluded that the building has significant deficiencies as related to its seismic resistance, although it should be noted that the building has a certain percentage of walls in both directions that could be considered satisfactory under certain conditions. The main deficiency is that the building has a considerable number of openings at main load bearing walls, i.e. at the walls that support steel girders and wooden beams of floor structures, which greatly reduces the stiffness and resistance of these walls. Other deficiencies that deserve to be mentioned include floor structures made of wooden beams that do not have sufficient in-plane stiffness to be considered as diaphragms, which is one of significant requirements in seismic analysis, as it equalizes displacements of all points in the structure and enables more regular redistribution of forces between load bearing elements. An additional deficiency is an insufficient connection between wooden joists beams and load bearing walls. Gable walls - unsupported along the entire length - are also problematic as they do not support floor structures. In the light of the above, it was concluded that the building is suitable for retrofitting and, considering its occupancy, the retrofit level 3 - structural strengthening - was selectid according to [3-5]. Repair and structural strengthening activities are also proposed in the report, taking into account the retrofitting level selected for this building.

\section{Structural retrofit design for the building}

The activities continued with preparation of the structural retrofit design in which details of realisation of all proposed repair and structural strengthening activities were further elaborated, an in which the mechanical and seismic resistance of the strengthened building was proven. The design for the level 3 was conducted for the limit state of significant damage, corresponding to a probability of exceedance of $20 \%$ in 50 years, i.e. for the return period of 225 years.

The program package 3Muri v. 12 [6] was used for proving mechanical resistance and stability and for estimating seismic resistance of the building. The calculation method used will be described, and the results will be presented for the unstrengthened building (building before earthquake) and for the repaired and strengthened building. The results will then be compared so as to find out to what extent the structure has been strengthened. A brief overview will be given of the structural interventions whose influence was taken into account in the calculation of the repaired and strengthened building.
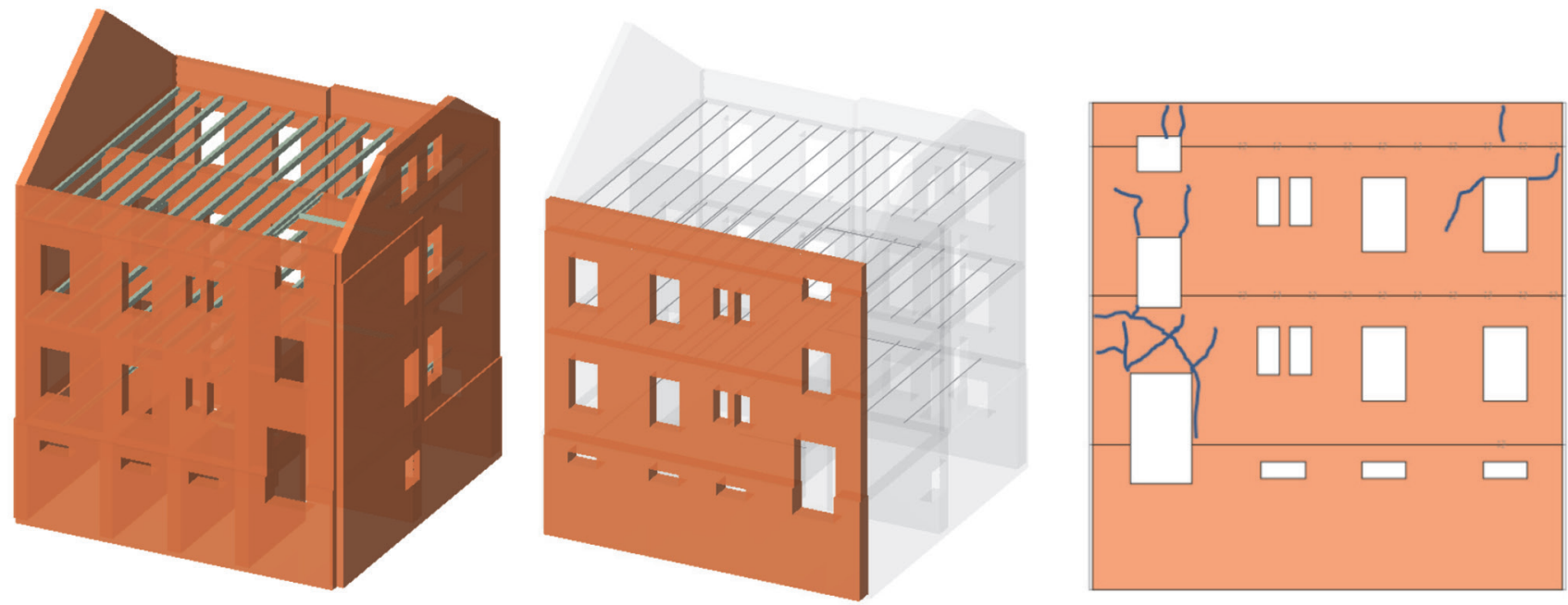

Figure 5. 3D model (left), typical east facade wall (centre), and damage marked at east facade wall (right) 

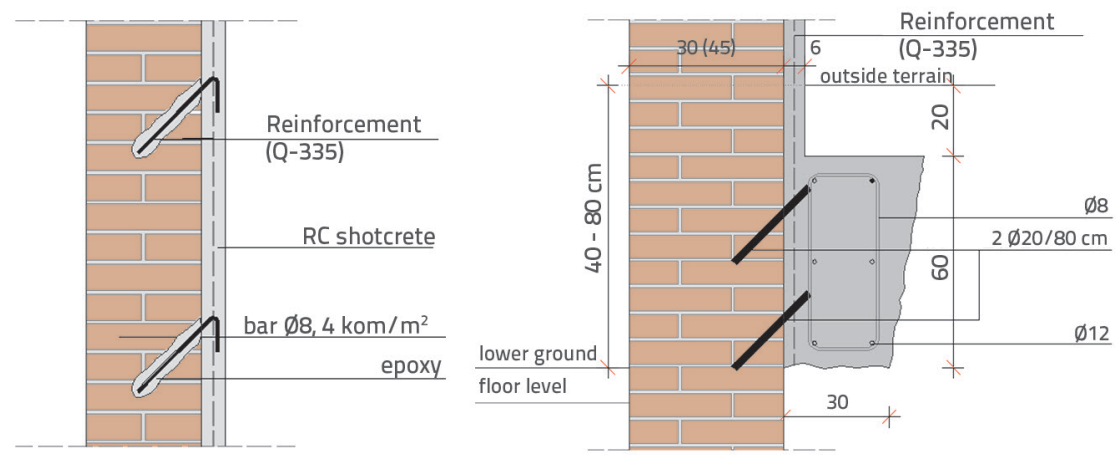

Figure 6. RC shotcrete and brick wall connection detail, detail (left), shotcrete foundation detail (right)

\subsection{Structural strengthening}

\subsubsection{Shotcreting of bearing walls}

Works aimed at increasing the load bearing capacity of walls consisted in one-sided shotcreting of facade walls, $6 \mathrm{~cm}$ in thickness. As the house is semi-detached, the south facade wall was shotcreted from the inside, while all other facade walls were shotcreted from the outside, which included realisation of new shotcreted strip foundation. Shotcreting activity details are shown in Figure 6.

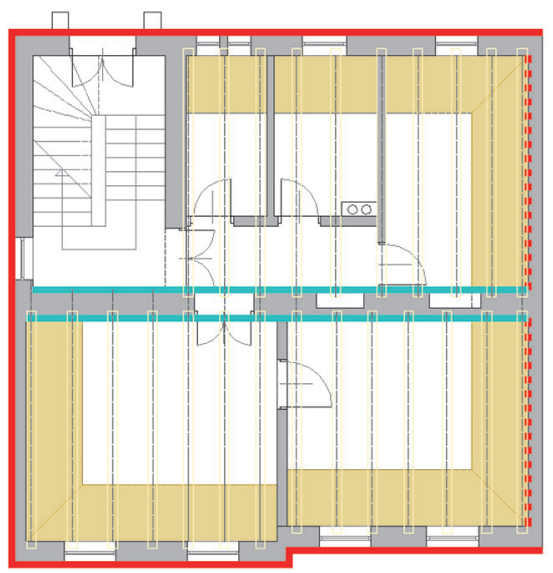

1. LAYER

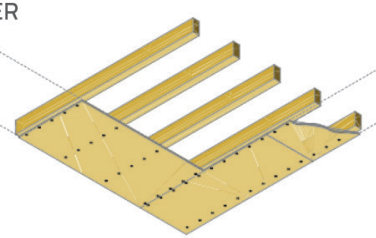

2. LAYER

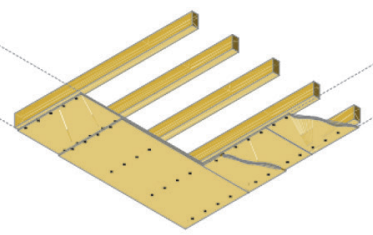

Figure 7. Plan of a typical floor with disposition of veneer plates (ochre colour), installation of steel section next to central wall (turquoise colour) and RC shotcrete (red colour) (left), and installation of veneer plate layers (right)

\subsubsection{Strengthening of floor structures}

To make sure that floor structures act as rigid diaphragms and to provide support to gable walls in case of horizontal action, floor structures were strengthened by placing two rows of veneer plates $1.2 \mathrm{~cm}$ in thickness and $125 \mathrm{~cm}$ in width on the bottom side of wooden joists at the ceiling of the ground floor and first floor. These veneer plates were connected to walls in accordance with specially defined details. The plan arrangement of plates is shown in Figure 7, which also shows shotcrete placement positions and the longitudinal $L$ section at the central wall, which is described below. The connection of gable walls and longitudinal facade walls to wooden beams of the ceiling is also planned. Figure 8 a shows a detail of the connection of longitudinal walls to the floor structure, which is operated by installation of M16 anchors that are welded on one side to the anchoring plate and fixed to the wooden beam with wood screws, while on the other end they are pulled through brick wall and are anchored on its external side via the base plate and nut connection. Such an intervention is made on every second beam. Gable walls are connected in a similar way but, in this case, the anchor passes through the edge wooden beam and is anchored on the other side. Figure $8 \mathrm{~b}$ shows connection of the central load bearing wall with wooden beams at the ceiling by installing two longitudinal steel $L$ sections on both sides of the wall, which are connected to each other by pull-through anchors spaced at $150 \mathrm{~cm}$ intervals.

\subsubsection{Repair of partition walls}

Partition walls are repaired by installing fiberglass fabric that are placed in a special factory-prepared mortar. At the construction site, water is added to that mortar and after mixing it is ready for use.

\subsection{Global analysis of the building}

\subsubsection{Muri and pushover method}

3Muri is an engineering software [6] for seismic analysis of the buildings whose load bearing system consists of masonry walls. The software uses non-linear static analysis method based on displacement, i.e. the so called "pushover analysis" or the incremental pushover method, which is considered to be one of the most appropriate methods for seismic analysis of the existing masonry structures [7]. The pushover analysis is conducted by subjecting the structure to horizontal load via forces representing inertia forces that the structure may experience during an earthquake event. The analysis consists of a series of non-linear static analyses for monotonously increasing horizontal forces that lead to plastic flow at individual cross sections, as well as to an increase in deformation of the structure and change in stiffness of the entire system that was previously subjected to vertical actions. By plasticization of the cross-section, i.e. by reaching the plastic value of resistance, the internal force in the element can no longer increase, but the element continues to deform. The maximum displacement capacity corresponds to displacement of the control node that is situated at the highest floor of the structure. At this displacement, the total transverse force at the base fell under $80 \%$ of its maximum value or 
a)

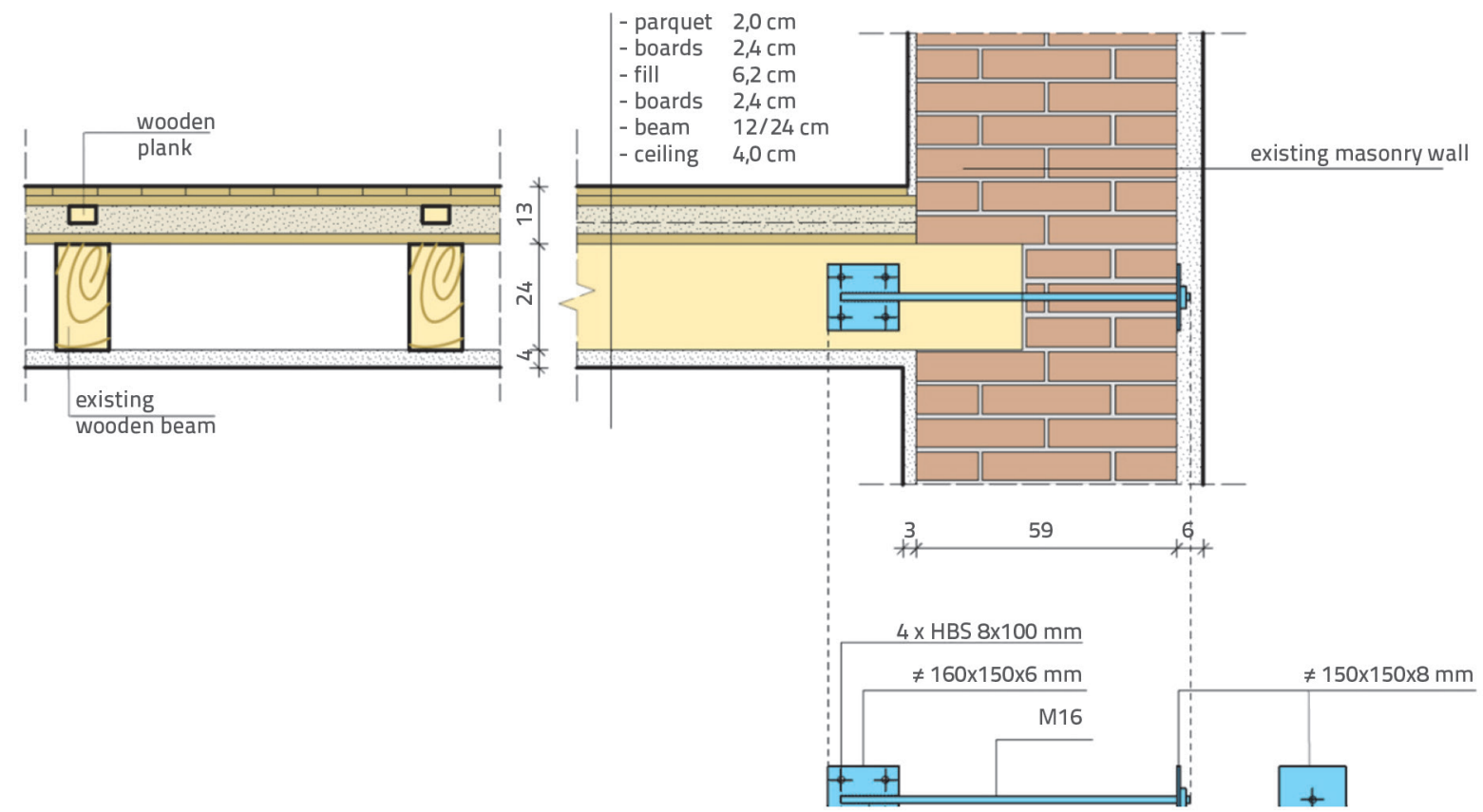

b)

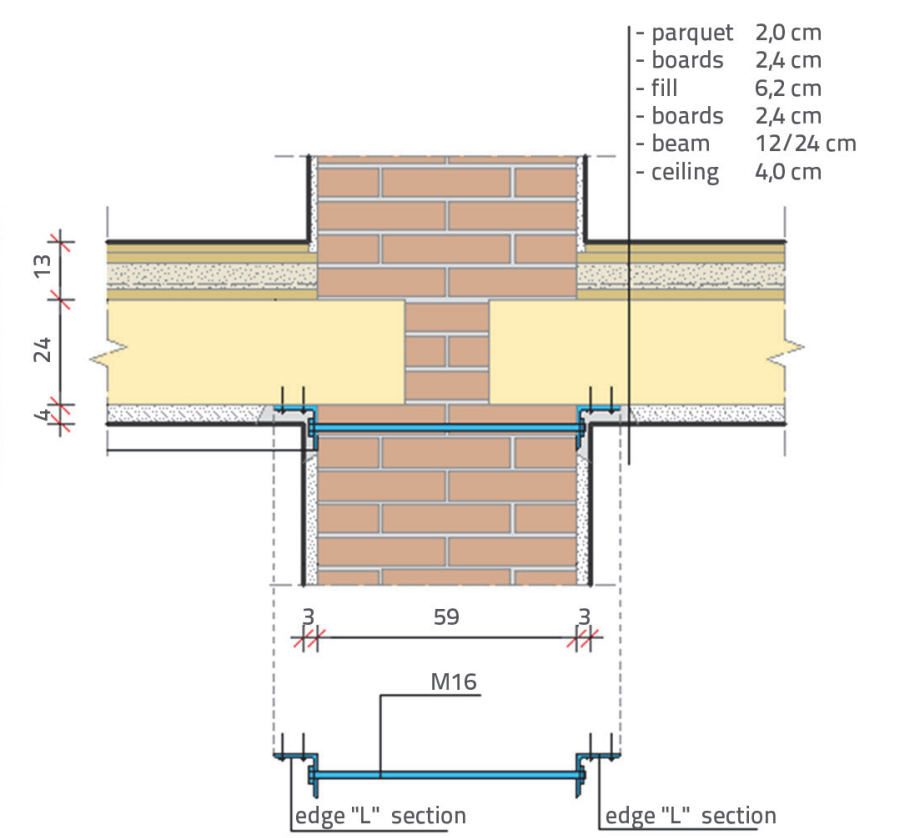

Figure 8. Connection of external walls (a) and central wall (b) with floor structure

resistance of the structure. The objective of the pushover analysis is to determine the relationship between the transverse force at the base and control node displacement, which is graphically presented by means of a pushover curve.

Selection of an appropriate model for the distribution of horizontal (lateral) forces along the height of the structure is an important step in the pushover analysis. Two horizontal force distribution models (involving implementation of the N2 method) are used by 3Muri software [6]:

- uniform distribution based on lateral forces that are proportional to the mass, regardless of elevation
- modal distribution based on lateral forces that are proportional to the first form of vibration of the structure.

In addition to selection of the lateral force distribution, it is also necessary to determine the so called control node, as the pushover curve is created based on displacement of this node. The control node is selected at the highest storey of the building, as close as possible to the centre of masses. The calculation according to the incremental pushover method is based on the assumption that the inelastic response of the structure can be compared with the response of an equivalent system with a single degree 
of freedom (ESDOF). The structure is modelled aa a system with several degrees of freedom (MDOF) that is subjected to nonlinear static calculation in the scope of which transformation is made for the system with several degrees of freedom (MDOF) to an equivalent system with a single degree of freedom (ESDOF), under assumption of equal form of deformation due to seismic forces. Maximum displacement is determined from non-linear calculation of an equivalent system with a single degree of freedom (ESDOF).

Finally, pushover curves obtained for each of the main directions are used for calculating the seismic resistance of buildings. The reference pushover curve is the curve resulting in poorer capacity of the structure with regard to deformation, stiffness and bearing capacity.

Proper modelling of the structure is extremely important as it increases accuracy of results. It is recommended to simplify the structure as much as possible, while maintaining necessary accuracy of the model. 3Muri is based on modelling walls as macro elements that enable two basic forms of the in-plane wall failure: failure due to bending, and failure due to shear. Macro elements are divided into three sub-elements: top and bottom layers where influences of the bending and longitudinal forces are concentrated, and the central layer that assumes shear deformations. Consequently, each wall is divided by the software according to the above pattern, and every wall is idealised by an equivalent frame that is formed of deformable piers and and spandrels, and of rigid elements between them that are not sensitive to damage (rigid joints) [8].

Some structural elements that do not greatly affect the response and resistance of structures (e.g. balconies, partition walls, staircases) are not modelled in order to avoid disturbance to the frequencies of the structure and to the distribution of masses. To simplify the model, the roof can be approximated as an additional load on the highest storey or, in this particular case, its shape is simplified by omitting from the model roof dormers and gable ends at the north facade. Extremely narrow wall elements, such as wall parts between two adjacent openings that have a common lintel, or wall elements not linked with floor structures, are usually the first to give way fail and so they should be avoided, unless their presence is absolutely necessary [9].

\subsubsection{Input parameters}

The characteristics of materials used in modelling of the building were assumed based on previous tests and analyses of buildings of similar geometry and year of construction [10]. The characteristics of materials used in the construction of walls are presented in Table 1.

Table 1. Characteristics of load bearing elements $\left(\mathrm{N} / \mathrm{mm}^{2}\right)$

\begin{tabular}{|c|c|c|c|}
\hline Designation & $\begin{array}{c}\text { Elastic } \\
\text { modulus }\end{array}$ & $\begin{array}{c}\text { Shear } \\
\text { modulus }\end{array}$ & $\begin{array}{c}\text { Mean shear } \\
\text { strength }\end{array}$ \\
\hline brick & 800.00 & 250.00 & 0.10 \\
\hline
\end{tabular}

Vertical loads (permanent load and service load) imposed on floor structures must be set in the model. The analysis is made for the seismic load combination according to HRN EN 1990, Section 6.4.3.4 [11]. A typical storey, with the corresponding load and direction of capacity of floor structures, is graphically presented in Figure 9. The soil category C was selected for seismic analysis.

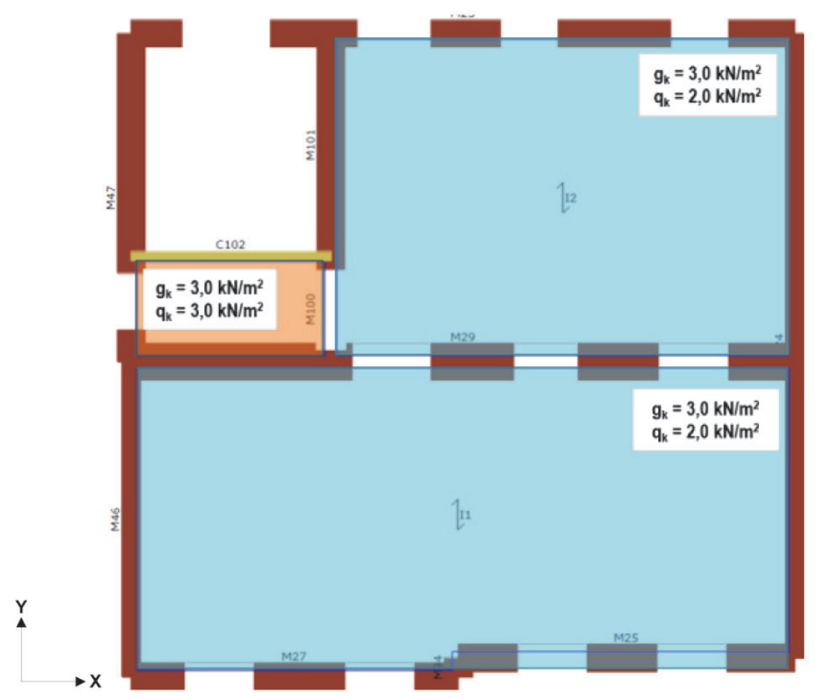

Figure 9. Representation of load imposed on a typical storey

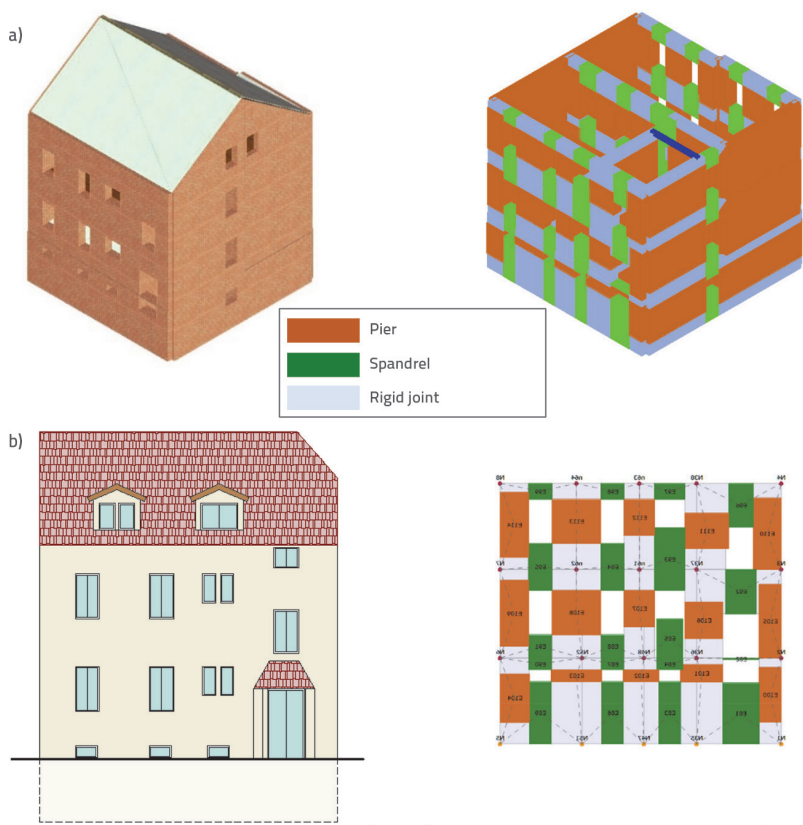

Figure 10. a) Presentation of 3D building model and replacement model with frames; b) Presentation of east-side wall modelled using replacement frames

The peak acceleration of soil for the return period of 475 years, amounting to $2.56 \mathrm{~m} / \mathrm{s}^{2}(0.26 \mathrm{~g})$, was used for the control of the limit state of significant damage (SD), while the peak acceleration of soil for the return period of 95 years, amounting 

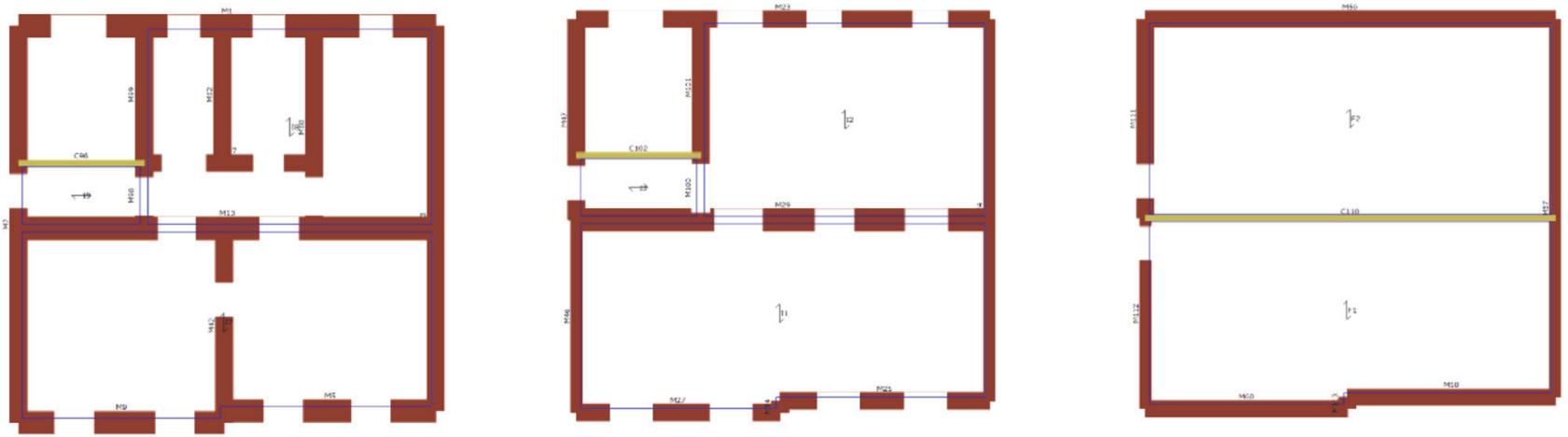

Figure 11. Plan view of the lower ground floor (left), first floor (centre), and attic (right)

to $1.28 \mathrm{~m} / \mathrm{s}^{2}(0.13 \mathrm{~g})$, was used for the control of limit state of damage limitation (DL), all according to HRN EN 1998-3 [12].

The building was modelled using the already described procedure, i.e. the walls were modelled as macro elements and were replaced with equivalent frames for the purposes of the analysis [13]. As the lower ground floor level is not significantly buried into soil, except for the yard side of the building, the decision was made to include it in the modelling and in the assessment of seismic resistance. The 3D model of the building, and the replacement model with frames, are shown in Figure 10a, while Figure 10b shows a typical wall oriented in $\mathrm{X}$ direction, where main elements of equivalent frames can be observed (piers, spandrels and rigid joints). All plan views of individual storeys, with the corresponding load bearing walls, are shown in Figure 11.

\subsubsection{Analysis}

3Muri software performs a total of 24 pushover analyses defined with four direction of lateral forces $(+X,-X,+Y$ and $-Y)$, with two types of lateral force distribution (uniform distribution and modal distribution), and with or without positive or negative eccentricity of lateral forces. Random eccentricity is used at every storey so as to take into account random torsional effects, and it amounts to $5 \%$ of the maximum building length orthogonal to the direction of lateral forces for an individual analysis. The node No. 34, situated at the highest storey of the building, near the centre of masses, was selected as control node [6].

The limit state of significant damage (SD) and the limit state of damage limitation (DL) must be controlled as specified in HRN EN 1998-3/NA, Section 2.2. The return period of limit state of significant damage is 475 years, while the return period of limit state of damage limitation is 95 years.

The following requirement has been set for the limit state of significant damage (SD):

$d_{t}^{S D} \leq d_{m}^{S D}$

where $d_{t}^{S D}$ is the target or required displacement, while $d_{m}^{S D}$ is the capacity of displacement for limit state of significant damage [6].
Requirement for the limit state of damage limitation (DL) is:

$S_{d}\left(T^{*}\right) \leq d_{y}^{*}$

where $S_{d}\left(T^{*}\right)$ is the target displacement required in the standard for $T=T^{*}$ ( $T^{*}$ is the ESDOF period), while $d_{y}{ }^{*}$ is the yield displacement of an equivalent system with one degree of freedom (ESDOF [5]).

peak acceleration, will be calculated for each limit state. The notion of compliance factor denotes the maximum value of the loads, taken into account in appropriate limit states, which the structure or the building is capable of withstanding [4].

$a_{S D}=P G A_{C S D} / P G A_{D S D}$
$a_{D L}=P G A_{C D L} / P G A_{D D L}$

where $P G A_{C S D}$ is the acceleration capacity corresponding to the limit state of significant damage, $P G A_{C D L}$ is the acceleration capacity corresponding to the limit state of damage limitation, $P G A_{D S D}$ is the peak soil acceleration that corresponds to the limit state of significant damage, and $P G A_{D D L}$ is the peak soil acceleration that corresponds to the limit state of damage limitation [6].

Calculation results will be presented for two models of the building under study: model $A$ and model $B$. Model $A$ represents the structure in its initial condition, i.e. in the condition before the 22 March 2020 earthquake. Model B represents the structure after the repair and structural strengthening works were carried out during the Summer and Autumn of 2020. In addition to analysis of the global response of the structure, one typical wall (west facade wall) will be considered separately in order to show how the strengthening influenced failure of individual wall elements. The results obtained will finally be compared in order to show to what extent the strengthening procedures undertaken increased the global seismic resistance of the building.

\section{a) Model A}

The calculation is carried out on an equivalent system with a single degree of freedom (ESDOF) using the following calculation parameters: period of vibration of an equivalent system $\mathrm{T}^{*}=0.764$ 
Table 2. Fulfilment factors for unstrengthened structure

\begin{tabular}{|c|c|c|c|c|c|}
\hline No. & Direction of seismic force & Type of distribution & Eccentricity [cm] & $\alpha$ SD & $\alpha \mathbf{D L}$ \\
\hline 1 & $+\mathrm{X}$ & uniform & 0.0 & 6.232 & 0.417 \\
\hline 2 & $+X$ & modal & 0.0 & 8.734 & 0.420 \\
\hline 3 & $-x$ & uniform & 0.0 & 0.401 & 0.441 \\
\hline 4 & $-X$ & modal & 0.0 & 0.347 & 0.399 \\
\hline 5 & $+Y$ & uniform & 0.0 & 0.257 & 0.559 \\
\hline 6 & $+Y$ & modal & 0.0 & 0.228 & 0.462 \\
\hline 7 & $-Y$ & uniform & 0.0 & 0.257 & 0.619 \\
\hline 8 & $-Y$ & modal & 0.0 & 0.224 & 0.534 \\
\hline 9 & $+X$ & uniform & 52.9 & 1.626 & 0.427 \\
\hline 10 & $+X$ & uniform & -52.9 & 4.711 & 0.399 \\
\hline 11 & $+X$ & modal & 52.9 & 13.007 & 0.483 \\
\hline 12 & $+X$ & modal & -52.9 & 9.176 & 0.465 \\
\hline 13 & $-X$ & uniform & 52.9 & 0.406 & 0.420 \\
\hline 14 & $-x$ & uniform & -52.9 & 0.396 & 0.456 \\
\hline 15 & $-X$ & modal & 52.9 & 0.344 & 0.372 \\
\hline 16 & $-X$ & modal & -52.9 & 0.357 & 0.402 \\
\hline 17 & $+Y$ & uniform & 54.0 & 0.228 & 0.540 \\
\hline 18 & $+Y$ & uniform & -54.0 & 0.268 & 0.535 \\
\hline 19 & $+Y$ & modal & 54.0 & 0.203 & 0.454 \\
\hline 20 & $+Y$ & modal & -54.0 & 0.243 & 0.579 \\
\hline 21 & $-Y$ & uniform & 54.0 & 0.221 & 0.590 \\
\hline 22 & $-Y$ & uniform & -54.0 & 0.286 & 0.686 \\
\hline 23 & $-Y$ & modal & 54.0 & 0.196 & 0.514 \\
\hline 24 & $-Y$ & modal & -54.0 & 0.243 & 0.598 \\
\hline
\end{tabular}

$\mathrm{s}$, transformation factor $\Gamma=1.25$, force at failure of an equivalent system (ultimate strength of idealized system) $\mathrm{F}_{\mathrm{y}}^{*}=542 \mathrm{kN}$, displacement at failure of an equivalent system $\mathrm{d}_{y}{ }^{*}=2.2 \mathrm{~cm}$, and maximum displacement of an equivalent system $\mathrm{d}_{\mathrm{m}}{ }^{*}=2.23 \mathrm{~cm}$. After calculation, compliance factors are tabularly presented by the software for each analysis and for both limit states (Table 2). If the compliance factor is greater than 1, the load bearing capacity requirement is considered fulfilled and the structure has a satisfactory capacity to assume seismic forces, i.e. structural displacements are smaller than limit displacements for the corresponding limit state defined by standard. Two reference analyses are marked in yellow, one for each direction. Green colour denotes the analysis that has met the requirements, while red colour denotes the analysis that has not met calculation requirements.

When all capacity curves are shown on the same diagram (Figure 12), it can clearly be seen that the structure has up to two times greater deformation capacity in direction $\mathrm{X}$ compared to direction $\mathrm{Y}$. This is due to the fact that shear walls with smaller openings are dominant in direction $Y$, while large and numerous openings dominate in direction $X$ so that such walls behave more like frames and are primarily resistant to bending action. The ultimate bearing capacity with respect to transverse forces amounts to $534 \mathrm{kN}$ for direction $\mathrm{X}$, while it amounts to $1038 \mathrm{kN}$ for direction $\mathrm{Y}$. As in the pushover method the deformation of the structure is more important than the ultimate bearing capacity, it can be concluded that the structure exhibits greater resistance in direction $\mathrm{X}$, as can also be seen in Table 2 where the factor of fulfilment values are greater in the analyses in which seismic force is assigned in direction $X$ as compared to the analyses in direction $Y$. The smallest compliance factor value was obtained in the analysis No. 23 and it amounts to 0.196. This means that the structure can withstand $19.6 \%$ of the design peak acceleration of soil for the return period of 475 years. The diagram with all capacity curves is shown in Figure 12. In this diagram, axis $x$ denotes displacement of the structure, while axis $y$ denotes transverse force in plan view.

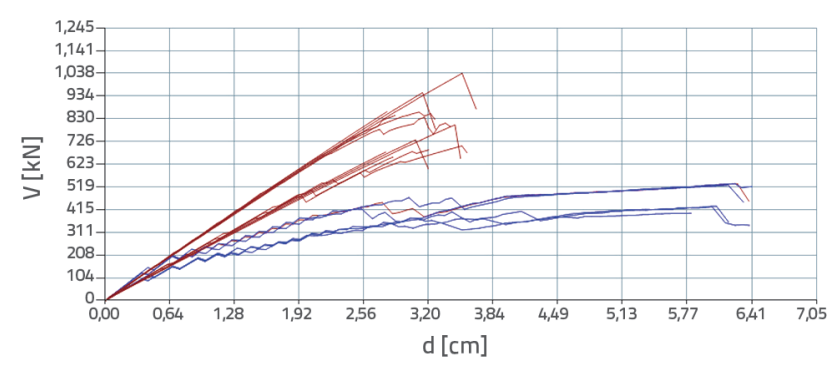

Figure 12. Capacity curves for both directions of seismic forces (blue colour denote direction $\mathrm{X}$, while red colour denotes direction $\mathrm{Y}$ ) 


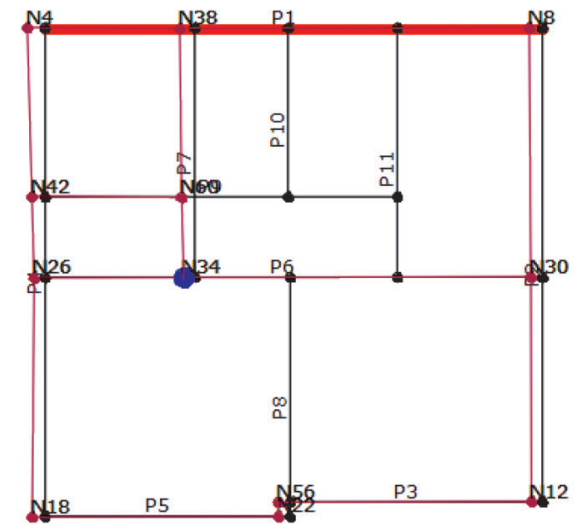

b)

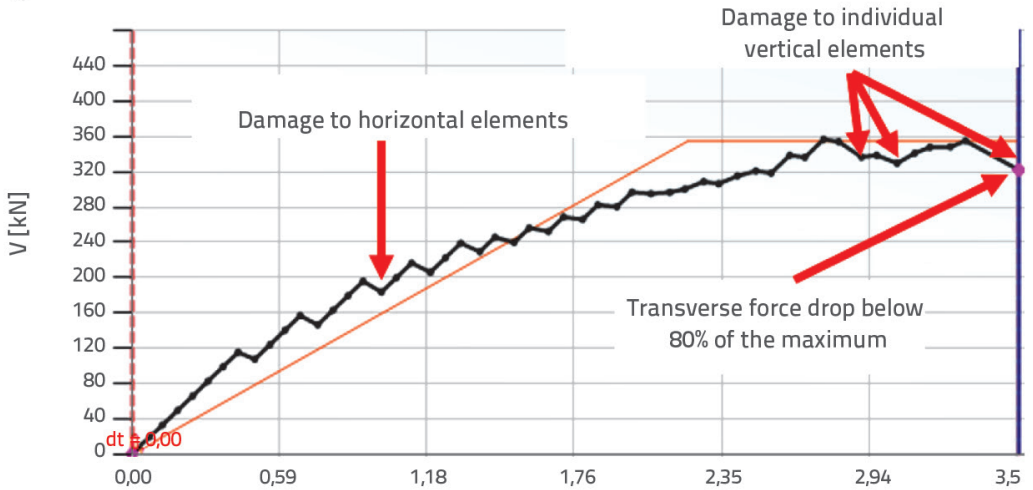

Figure 13. a) Plan view of load bearing walls with deformation line; b) capacity curve of the building for analysis No. 15

The west facade wall is considered as a separate wall in the scope of reference analysis for direction X (analysis No. 15).

Figure 13 shows plan view on which the wall considered in the analysis is marked. The same figure also shows the capacity curve for the entire building, as obtained in the scope of analysis No. 15. At the beginning of the analysis, the response of the structure is approximately elastic with zig-zag line that is typical for all masonry structures. The curve starts to flatten with and increase in displacement or deformation, and the behaviour of the structure becomes non-linear. The damage to elements causes greater

a)
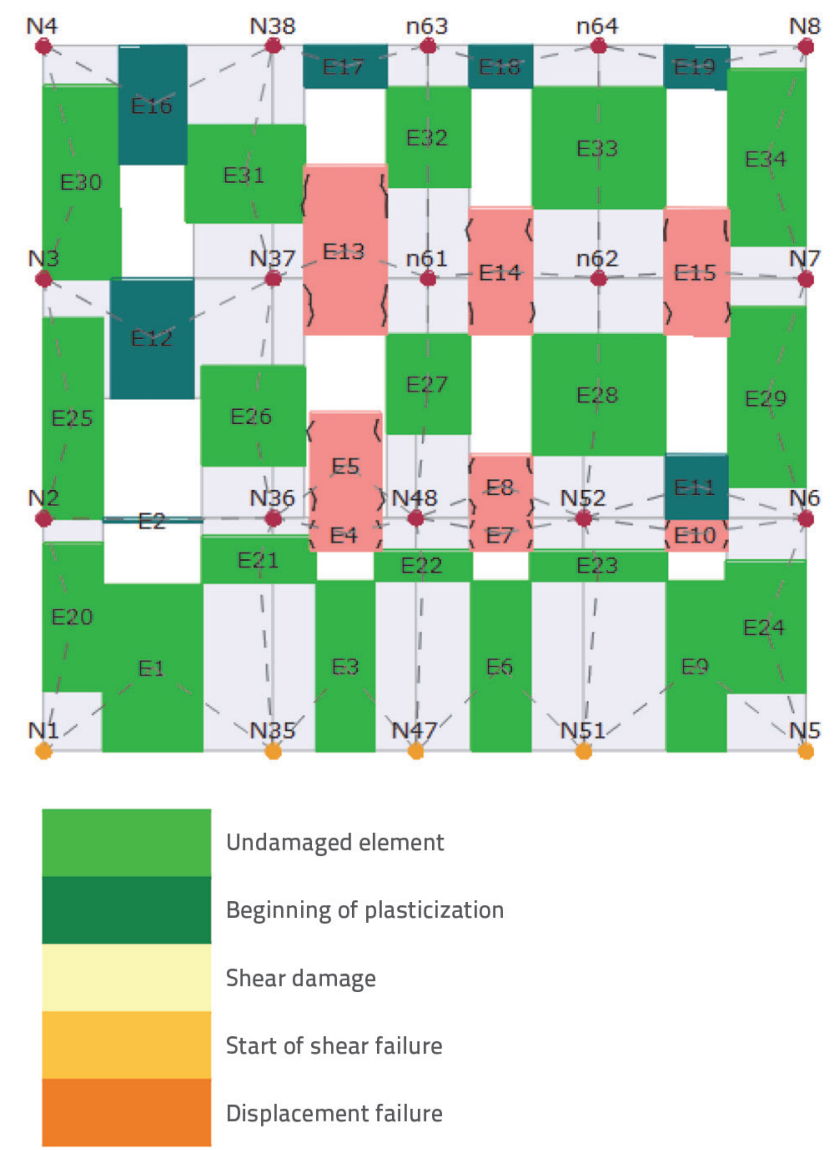

flattening of the curve or its negative increase, which is followed by redistribution of load onto the remaining elements and by slight increase in force in the next step. The analysis ends when the force falls to $80 \%$ of the maximum transverse force.

Figure 14 a shows a typical wall and development of damage in that wall with the advancement of the analysis. Damage due to bending occurs at some horizontal elements already at initial steps of application of lateral forces. As damage to these elements can be considered acceptable, the analysis continues until failure of the global system.

b)
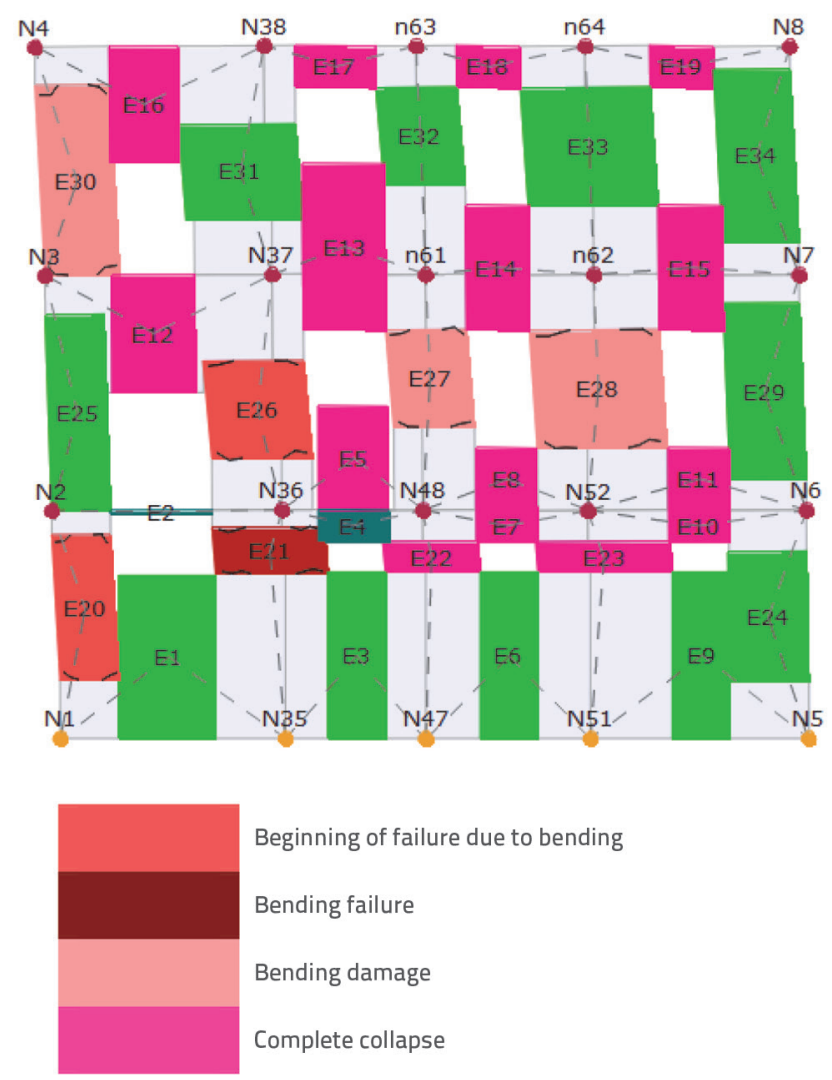

Beginning of failure due to bending

Bending failure

Bending damage

Complete collapse

Figure 14. Development of damage in typical wall in the Analysis No. 15: a) at the start of the analysis; b) at the end of the analysis 
Figure 14b shows the end of the analysis No. 15. It can be observed that most horizontal elements (spandrels) have failed or are damaged due to bending. A number of vertical elements (piers) have suffered damage due to bending (E30, E27, E28), walls E26 and E20 are about to fail due to bending, while walls E21, E22 and E23 have already failed due to bending. Wall failure is manifested in Figure 14b as a sudden drop of capacity curve.

\section{b) Model B}

Model $B$ is related to the strengthened structure. Interventions made to strengthen the structure have been described in previous sections of this paper. Model B was therefore corrected based on these interventions by adding to the existing brick walls a layer of steel reinforcement corresponding to the reinforcement of the placed shotcrete (Q-335), while two layers of veneer plates were added at the level of floor structures so as to increase rigidity of the connection between wooden beams and load bearing walls (in the transverse direction). By adding these two veneer plate layers, as an addition to the already existing one-sided planking (at the ceiling of the lower ground floor level) and both-sided planking (at floor structures), the rigidity of the floor structures was increased to such an extent that they can be considered as diaphragms sufficiently rigid in their plane for the analysed arrangement of load bearing walls.
As shotcrete could not be added to the software as a wall strengthening material, it was simulated by adding reinforcement to masonry walls in the designed and installed quantity (reinforcement mesh type Q-335 with strengthenings around openings by means of longitudinal $\Phi 12$ reinforcement bars), and the elastic and shear moduli values were corrected in the material selection menu. Several calculations of the same model were made at that moment with various elastic modulus and displacement values, in order to select the values of these parameters that would best describe the new strengthened condition of the structure. The calculation of the elastic modulus and shear modulus was based on the rigidity of the strengthened wall which is equal to the sum of rigidities of the brick masonry wall and rigidity of the reinforced-concrete gunite (shotcrete) [10]. As the rigidity of shotcrete is by several times greater than the rigidity of the brick masonry wall, it can be considered that the entire horizontal force will be assumed by shotcrete [14]. Material properties shown in Table 3 were finally selected.

Table 3. Characteristics of load bearing elements (N/ $\left.\mathrm{mm}^{2}\right)$

\begin{tabular}{|c|c|c|c|}
\hline Designation & $\begin{array}{c}\text { Elastic modulus } \\
{\left[\mathrm{N} / \mathrm{mm}^{2}\right]}\end{array}$ & $\begin{array}{c}\text { Shear modulus } \\
{\left[\mathrm{N} / \mathrm{mm}^{2}\right]}\end{array}$ & $\begin{array}{c}\text { Mean shear strength } \\
{\left[\mathrm{N} / \mathrm{mm}^{2}\right]}\end{array}$ \\
\hline $\begin{array}{c}\text { brick + } \\
\text { shotcrete }\end{array}$ & 3000.00 & 1000.00 & 0.10 \\
\hline
\end{tabular}

Table 4. Fulfilment factor for strengthened structure

\begin{tabular}{|c|c|c|c|c|c|}
\hline No. & Direction of seismic force & Type of distribution & Eccentricity [cm] & $\alpha$ SD & $\alpha \mathbf{D L}$ \\
\hline 1 & $+X$ & uniform & 0.0 & 1.224 & 1.840 \\
\hline 2 & $+X$ & modal & 0.0 & 1.127 & 1.448 \\
\hline 3 & $-X$ & uniform & 0.0 & 1.009 & 1.467 \\
\hline 4 & $-x$ & modal & 0.0 & 0.835 & 1.094 \\
\hline 5 & $+Y$ & uniform & 0.0 & 1.508 & 2.440 \\
\hline 6 & $+Y$ & modal & 0.0 & 1.587 & 2.190 \\
\hline 7 & $-Y$ & uniform & 0.0 & 1.686 & 2.767 \\
\hline 8 & $-Y$ & modal & 0.0 & 1.716 & 2.359 \\
\hline 9 & $+X$ & uniform & 52.9 & 1.254 & 1.842 \\
\hline 10 & $+X$ & uniform & -52.9 & 1.093 & 1.784 \\
\hline 11 & $+X$ & modal & 52.9 & 1.057 & 1.503 \\
\hline 12 & $+X$ & modal & -52.9 & 1.153 & 1.343 \\
\hline 13 & $-x$ & uniform & 52.9 & 1.052 & 1.411 \\
\hline 14 & $-X$ & uniform & -52.9 & 1.046 & 1.488 \\
\hline 15 & $-X$ & modal & 52.9 & 0.861 & 1.066 \\
\hline 16 & $-X$ & modal & -52.9 & 0.768 & 1.060 \\
\hline 17 & $+Y$ & uniform & 54.0 & 1.501 & 2.515 \\
\hline 18 & $+Y$ & uniform & -54.0 & 1.458 & 2.375 \\
\hline 19 & $+Y$ & modal & 54.0 & 1.557 & 2.272 \\
\hline 20 & $+Y$ & modal & -54.0 & 1.453 & 2.075 \\
\hline 21 & $-Y$ & uniform & 54.0 & 1.661 & 2.691 \\
\hline 22 & $-Y$ & uniform & -54.0 & 1.672 & 2.696 \\
\hline 23 & $-Y$ & modal & 54.0 & 1.707 & 2.443 \\
\hline 24 & $-Y$ & modal & -54.0 & 1.666 & 2.233 \\
\hline
\end{tabular}


and the following calculation parameters: vibration period of the equivalent system $T^{*}=0,282 \mathrm{~s}$, transformation factor $\Gamma=1.24$, force at failure of the equivalent system (ultimate strength of idealized system) $\mathrm{F}_{\mathrm{y}}{ }^{*}=1326 \mathrm{kN}$, displacement at failure of the equivalent system $\mathrm{d}_{\mathrm{y}}{ }^{*}=0.79 \mathrm{~cm}$ and maximum displacement of the equivalent system $d_{m}{ }^{*}=2.05 \mathrm{~cm}$. Compliance factors for each analysis and for both limit states after repeated calculation are shown in Table 4.

The representation of all capacity curves on a single diagram (Figure 15) reveals that the structure has approximately the same deformation capacity in both directions. The limit resistance to shear load is $3132 \mathrm{kN}$ for direction $\mathrm{X}$, while it is $4450 \mathrm{kN}$ for direction $\mathrm{Y}$. The data given in Table 4 and capacity curves shown in Figure 15 reveal that structural interventions have greatly contributed to an increase in structural resistance in both directions, especially in direction $Y$, where the deformation capacity of the structure has increased by at least two times. The minimum compliance factor value is the one from the analysis No. 16 and it amounts to 0.768 . This means that the structure is capable of withstanding $76.8 \%$ of the design peak acceleration of soil for the return period of 475 years. A diagram of all capacity curves is shown in Figure 15 where axis $x$ denotes the displacement of the structure, while axis y denotes the transverse force in plan view.

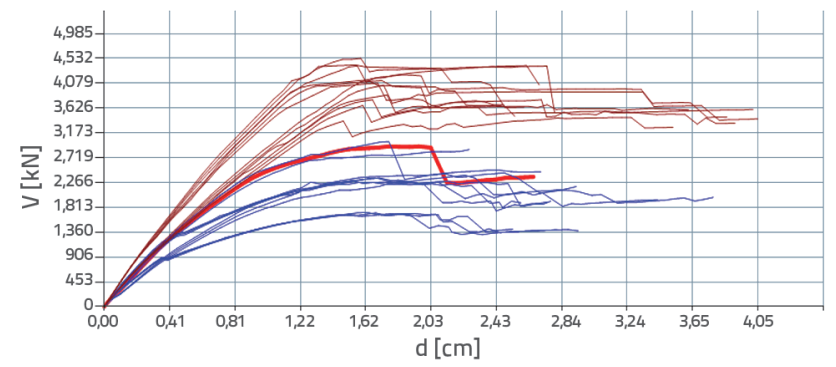

Figure 15. Capacity curves for both directions of seismic action (blue colour denotes direction $\mathrm{x}$, and the red colour denotes direction $\mathrm{Y}$ )

The typical wall on which strengthening interventions were made is considered once again. The corresponding capacity
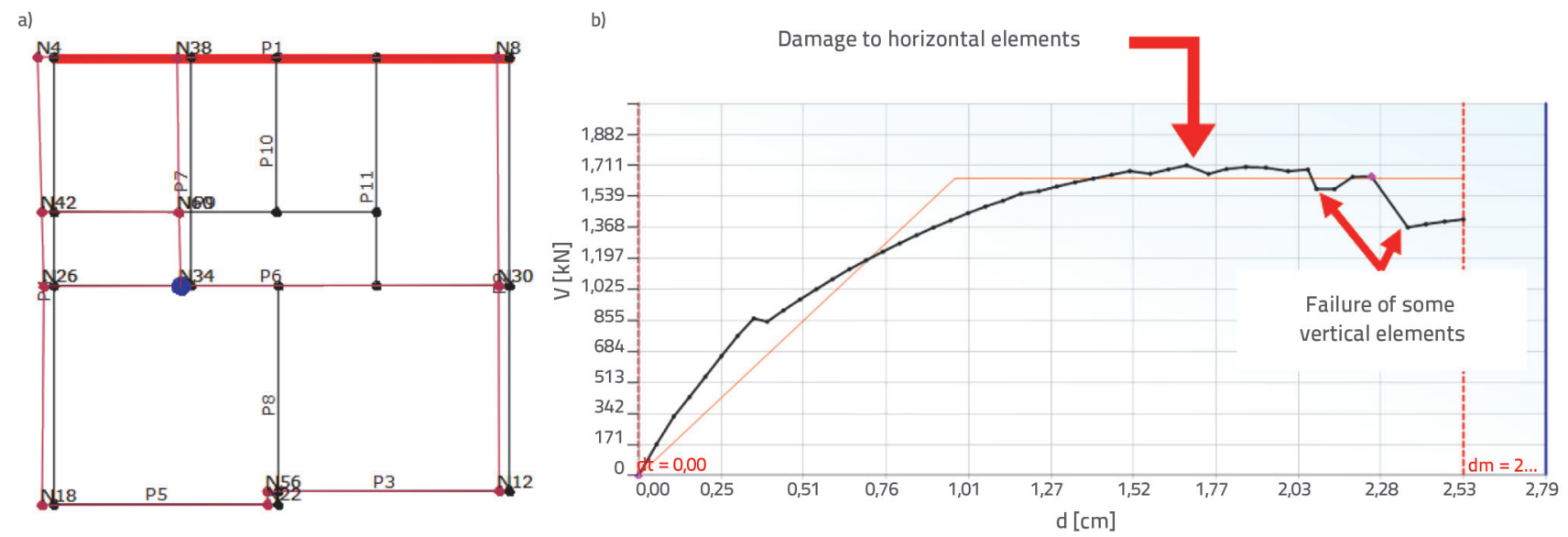

curve for the entire building, given in Figure 16, reveals a much greater period of action in which the structure still behaves in an elastic manner. After the displacement of about $1.7 \mathrm{~cm}$, damage occurs at some elements and the force is redistributed to the remaining elements. The failure finally occurs at the displacement of $2.5 \mathrm{~cm}$.

Figure 17a shows a typical wall and development of damage in that wall with the advancement of calculation. The first shear failure of horizontal elements (spandrels E59 - lintel above the first floor windows) occurs at the displacement of $1.86 \mathrm{~cm}$. In addition, damage due to bending and shear also occurs at parapets and lintels of lower storeys. Vertical elements (piers) have not as yet started to fail, but they do exhibit some damage due to bending (E63 and E64).

Wall condition after the analysis No. 16 is shown in Figure 17b. It can be seen in that figure that no vertical element failed in the observed wall at the displacement of $2.53 \mathrm{~cm}$, but that some of them suffered bending damage (E63, E64, E68 and E69). As to horizontal elements, some lintels and parapets at higher storeys failed, but most of other elements suffered damage due to bending and displacement. Considering that no global collapse occurred at the observed wall, the drop in capacity curve of the building is due to failure of an element in another wall.

\subsubsection{Analysis of implemented calculations}

The calculation is made using an equivalent system with a single degree of freedom (ESDOF). In the case of Model A, the structure did not meet requirements regarding limit state of damage limitation in any of 24 analyses, while it met deformability requirements in six analyses with regard to limit state of significant damage. At that, the most unfavourable was the analysis in which the structure was capable of assuming only $19.6 \%$ of the design peak acceleration of soil for the return period of 475 years. The structure has proven to be much weaker in direction $Y$, where the realized displacement of the structure is up to two times smaller than the displacement in direction $\mathrm{X}$.

Figure 16. a) Plan view of load bearing walls with deformation line; b) building capacity curve for analysis No. 16 

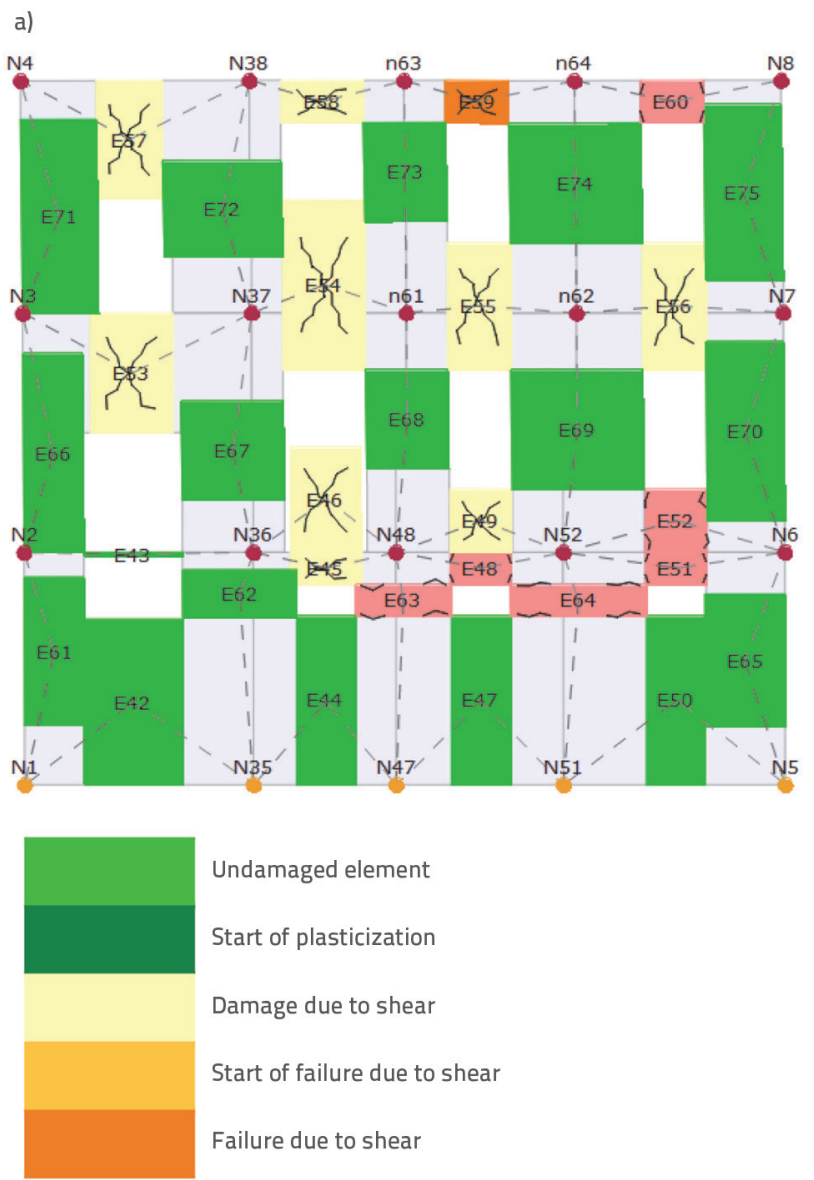

Figure 17. Development of damage in typical wall in the Analysis No. 16: a) at the start of calculation, b) at the end of calculation

In the case of Model B, the structure met deformability requirements in all analyses for the limit state of damage limitation, while for the limit state of significant damage it met deformability requirements in 21 analyses. At that, the least favourable was the analysis in which the structure was capable of withstanding $76.8 \%$ of the design peak acceleration of soil for the return period of 475 years. The structure has proven to be somewhat weaker in direction X, but in this model the deformability of the structure was approximately the same in both directions (in direction $Y$ the displacement increased by more than two times). The structure met requirements for the limit state of significant damage for direction $Y$ and so it can be considered that, for that direction, the structure has the bearing capacity of $100 \%$ with regard to seismic action for a probability of exceedance of $10 \%$ in 50 years (return period of 475 years).

For Model $A$, the maximum amount of transverse force at the base amounts to $534 \mathrm{kN}$ and $1038 \mathrm{kN}$ for directions $X$ and $Y$, respectively. b)

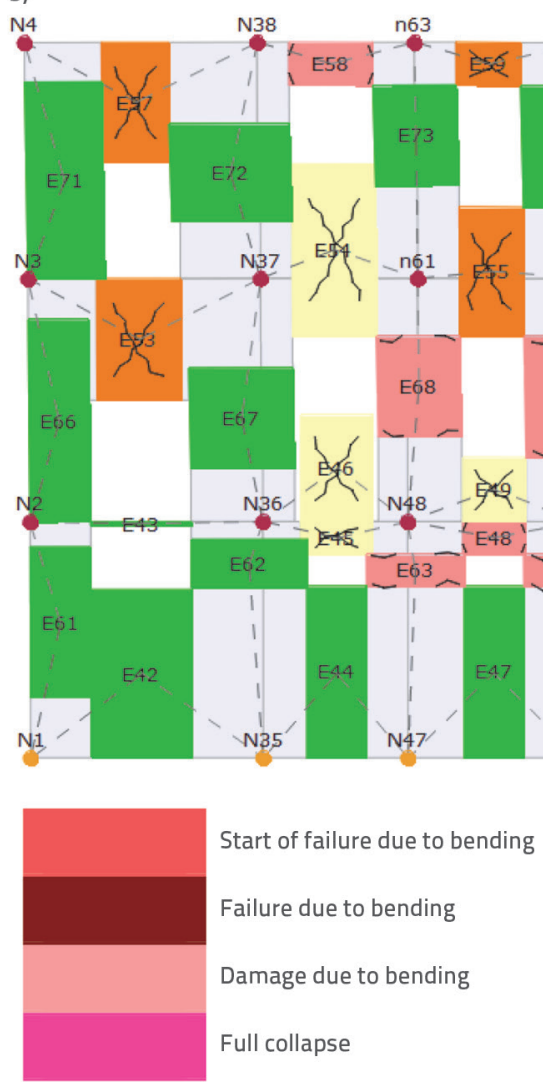

Table 5. Comparison of fulfilment factors for both models

\begin{tabular}{|c|c|c|c|c|c|c|}
\hline \multirow[b]{2}{*}{ Model } & \multicolumn{3}{|c|}{ Limit state of significant damage } & \multicolumn{3}{|c|}{ Limit state of damage limitation } \\
\hline & $P G A_{D S D}\left[\mathrm{~m} / \mathrm{s}^{2}\right]$ & $P G A_{C S D}\left[\mathrm{~m} / \mathrm{s}^{2}\right]$ & $a_{S D}$ & $P G A_{D D L}\left[\mathrm{~m} / \mathrm{s}^{2}\right]$ & $\mathbf{P G} \mathbf{A}_{\mathrm{CDL}}\left[\mathrm{m} / \mathrm{s}^{2}\right]$ & $a_{D L}$ \\
\hline A & 2.56 & 0.501 & 0.196 & 1.28 & 0.658 & 0.514 \\
\hline B & 2.56 & 1.967 & 0.768 & 1.28 & 1.357 & 1.060 \\
\hline
\end{tabular}

In the case of Model B, transverse force values increase significantly and amount to $3132 \mathrm{kN}$ and $4450 \mathrm{kN}$ for directions $X$ and $Y$, respectively. This increase in transverse forces is due to an increase in rigidity and bearing capacity of structural elements after their strengthening by the above mentioned interventions. Finally, the increase in seismic resistance of the structure, registered after the strengthening interventions, is presented through comparison of compliance factors for both models, as shown in Table 5. According to the data given in Table 5, it can be concluded that the mentioned interventions on the load bearing structure of the building resulted in achievement of the necessary global seismic resistance of the structure for a probability of exceedance of $10 \%$ in 10 years (return period of 95 years) for the limit state of damage limitation. By interventions to the load bearing structure of the building, the global seismic resistance of the structure for a probability of exceedance of $10 \%$ in 50 years (return period of 475 years) was 
not achieved in the absolute amount of $100 \%$ for the limit state of significant damage, but the resistance of the structure increased by 3.9 times when compared to the unstrengthened structure. The level of resistance of the building in comparison with the required resistance amounts to $76.8 \%$ for a probability of exceedance of 10 $\%$ in 50 years. Considering that the retrofit level 3 (probability of exceedance of $20 \%$ in 50 years or the return period of 225 years) was selected in the structural retrofit design for the building, in which case the horizontal peak acceleration of soil amounts to $\mathrm{a}_{\mathrm{g}}=0,18 \mathrm{~g}$, which is $70 \%$ of the horizontal peak acceleration of soil for the return period of 475 years, it can be concluded that the required level of retrofit has in fact been achieved by this structural strengthening. A detailed bill of quantities, with proper description of all works, was made in the scope of the design for structural retrofit of the building. This bill of quantities was used by the investor as a basis for selecting the contractor for these works.

\section{Realisation and supervision of works}

Renovation works for this building started already in the summer of 2020. All works werecarried outinaccordance with thecorresponding structural retrofit design, and included designer's supervision and expert supervision of works. Very delicate details had to be realized during construction works, especially during removal of old parts of the plaster, due to possible wall collapse situations as a result of deterioration of more than one-hundred-year-old bricks at some parts of facade walls. It should be noted that these works require highly trained personnel and a considerable expertise, which was ensured on this project, largely due to good cooperation between the contractor and the supervision team. Due to uneven surface and irregularities in facade walls, the shotcreting thickness attained up to $10-12 \mathrm{~cm}$ at some parts of facade walls, instead of the planned 6 $\mathrm{cm}$. This shotcreting was made by mechanically projecting shotcrete in three layers. The quality of concrete was occasionally checked during realisation of the works, which included checking quality of concrete used for shotcreted foundations, and ready-made factory produced shotcrete for the strengthening of external walls. The results are presented in Tables 6 and 7.

Some details of the construction work are shown in the following photographs (figures 18, 19, and 20). It can be seen that in some technical solutions, steel was used to achieve seismic resistance due to its numerous advantages in accordance with [15]. Thanks to properly coordinated work of all participants in this renovation project, with combined efforts by the investor, designer and contractor, all works were successfully completed in the winter of 2020.

Table 6. Results obtained by testing concrete for shotcreted foundations

\begin{tabular}{|c|c|c|c|c|}
\hline Designation of samples & $\begin{array}{c}\text { Sampling } \\
\text { [dd.mm.yyyy. }\end{array}$ & $\begin{array}{c}\text { Failure force } \\
{[\mathrm{kN}]}\end{array}$ & $\begin{array}{c}\text { Compressive strength } \\
{\left[\mathrm{N} / \mathrm{mm}^{2}\right]} \\
\text { on samples }\end{array}$ & $\begin{array}{c}\text { Compressive strength } \\
{\left[\mathrm{N} / \mathrm{mm}^{2}\right]} \\
\text { Mean value }\end{array}$ \\
\hline B1 & & 694.38 & 30.90 \\
\hline B2 & 14.08 .2020$. & 625.93 & 27.78 & 28.74 \\
\hline B3 & & 621.01 & 27.53 & \\
\hline B4 & & 580.77 & 25.74 & 25.66 \\
\hline B5 & 20.08 .2020$. & 572.43 & 25.41 & \\
\hline B6 & & 585.34 & 25.83 & \\
\hline
\end{tabular}

Table 7. Results obtained by testing ready-made shotcrete for strengthening external walls of the structure

\begin{tabular}{|c|c|c|c|c|c|c|c|c|c|c|}
\hline \multirow{2}{*}{$\begin{array}{l}\text { Designation of } \\
\text { samples }\end{array}$} & \multicolumn{3}{|c|}{ Dimensions [mm] } & \multirow{2}{*}{$\begin{array}{c}\text { Failure } \\
\text { force - } \\
\text { bending } \\
{[\mathrm{kN}]}\end{array}$} & \multirow{2}{*}{$\begin{array}{l}\text { Bending } \\
\text { strength } \\
{\left[\mathrm{N} / \mathrm{mm}^{2}\right]}\end{array}$} & \multicolumn{2}{|c|}{$\begin{array}{c}\text { Failure force - } \\
\text { compression [kN] }\end{array}$} & \multicolumn{3}{|c|}{ Compressive strength $\left[\mathrm{N} / \mathrm{mm}^{2}\right]$} \\
\hline & $b$ & h & d & & & Testing 1 & Testing 2 & Testing 1 & Testing 2 & $\begin{array}{l}\text { Mean } \\
\text { value }\end{array}$ \\
\hline TORKRET1 3d & 41.5 & 40.1 & 160.5 & 2.18 & 4.90 & 50.22 & 53.27 & 31.39 & 33.29 & 32.34 \\
\hline TORKRET2 3d & 41.0 & 40.5 & 160.4 & 2.32 & 5.17 & 52.76 & 53.96 & 32.98 & 33.73 & 33.35 \\
\hline TORKRET3 3d & 39.9 & 41.0 & 160.5 & 2.44 & 5.45 & 53.98 & 52.21 & 33.74 & 32.63 & 33.18 \\
\hline TORKRET4 7d & 40.1 & 40.8 & 160.6 & 2.38 & 5.35 & 66.65 & 66.17 & 41.66 & 41.63 & 41.51 \\
\hline TORKRET5 7d & 40.9 & 40.0 & 160.1 & 2.55 & 5.85 & 66.61 & 67.82 & 41.63 & 42.39 & 42.01 \\
\hline TORKRET6 7d & 40.6 & 39.7 & 160.0 & 2.96 & 6.94 & 67.51 & 67.25 & 42.19 & 42.03 & 42.11 \\
\hline TORKRET7 28d & 40.3 & 40.7 & 160.2 & 2.23 & 5.01 & 81.18 & 80.85 & 50.74 & 50.53 & 50.63 \\
\hline TORKRET8 28d & 40.1 & 40.6 & 160.2 & 2.93 & 6.65 & 79.92 & 80.80 & 49.85 & 50.50 & 50.23 \\
\hline TORKRET9 28d & 40.2 & 39.8 & 160.2 & 2.27 & 5.35 & 79.72 & 85.32 & 49.83 & 53.33 & 51.58 \\
\hline
\end{tabular}



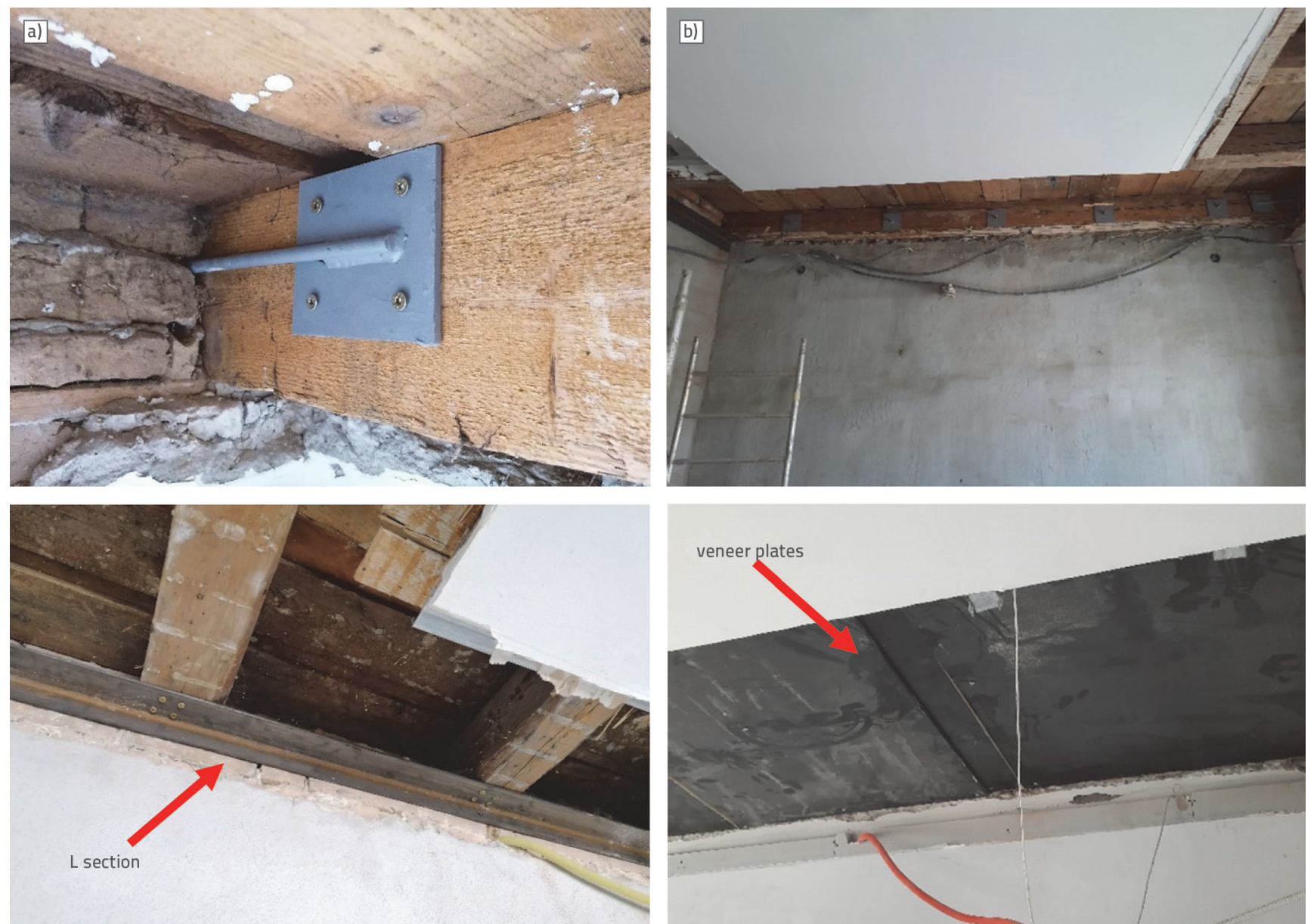

c)

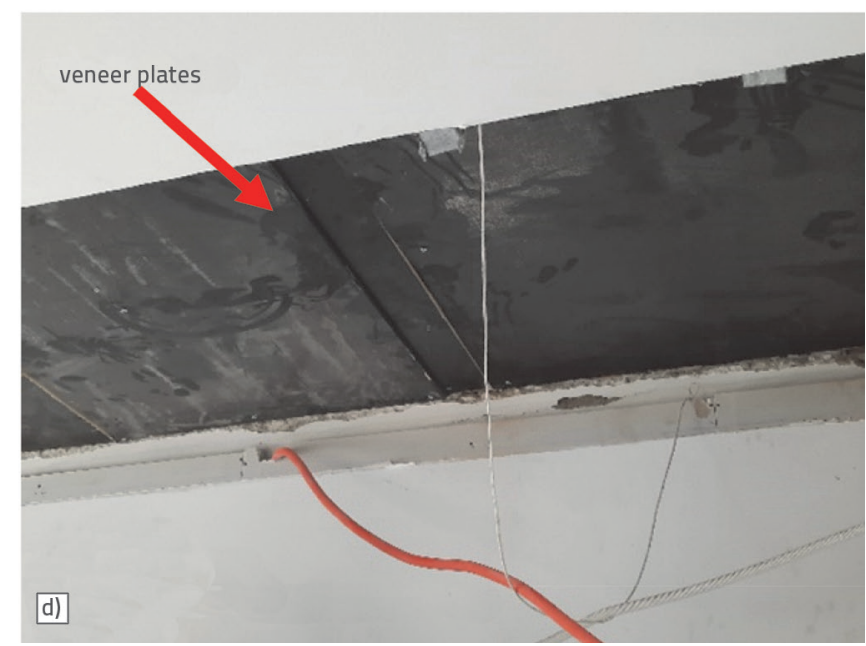

Figure 18. a) Connection of wooden joists to external west-side wall by anchoring, b) connection of external gable wall to wooden joists, c) use of $L$ section to connect central wall to wooden joists, $d$ ) placing veneer plates in two layers
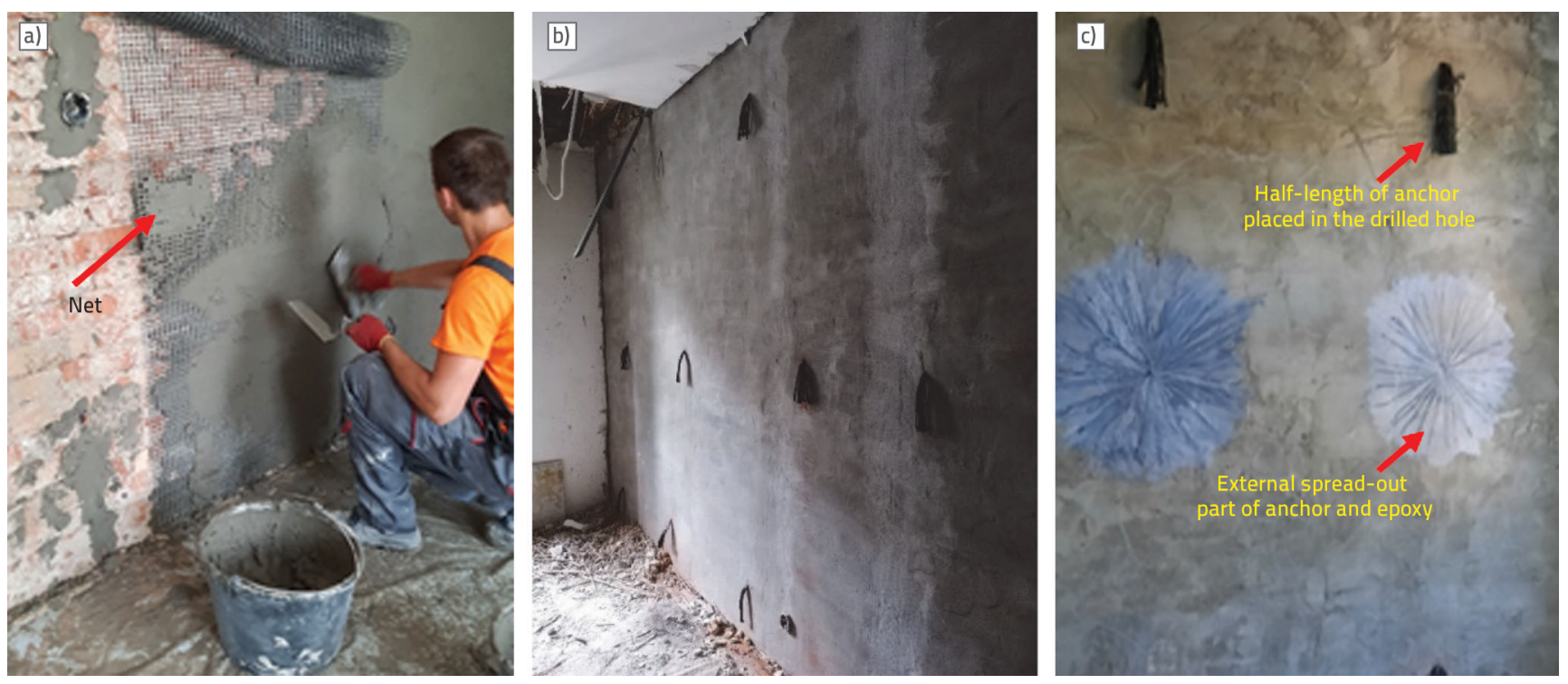

Figure 19. Strengthening of load bearing walls by installing glass fibre nets and carbon fibre anchors made by hand on the site, spaced at one square meter intervals 

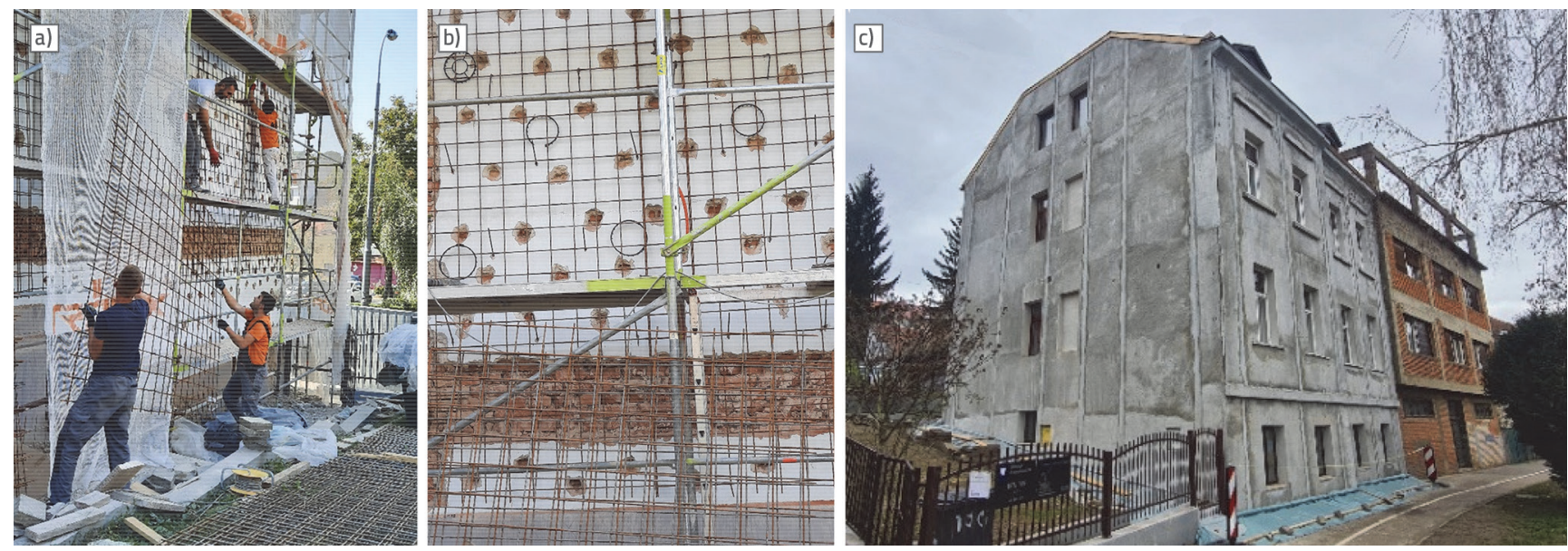

Figure 20. a) Realisation of shotcreting work, placing shotcrete reinforcement b), installation of supports, c), structure fully strengthened with shotcrete

\section{Conclusion}

The wish of the authors of this paper was to present the phases that have to be carried out so that a building damaged in the earthquake that struck Zagreb on 22 March 2020 can be renovated and strengthened to the required level of seismic resistance. All procedures planned in the scope of this renovation were performed in accordance with regulations passed after the said earthquake, including Technical regulation on the changes and additions to the Technical regulation for civil engineering structures Appendix III, Levels of renovation of earthquake-damaged structures relating to mechanical resistance and stability (Official Gazette No. 75/20), Law on renovation of earthquake-damaged buildings in the City of Zagreb, Krapina-Zagorje County and Zagreb County (Official Gazette No. 102/20), and the First program of measures for the renovation of earthquake-damaged buildings in the City of Zagreb, Krapina-Zagorje County and Zagreb County IOfficial Gazette No.

\section{REFERENCES}

[1] Šavor Novak, M., Uroš, M., Atalić, J., Herak, M., Demšić, M., Baniček, M., Lazarević, D., Bijelić, N., Crnogorac, M., Todorić, M.: Zagreb earthquake of 22 March 2020 - preliminary report on seismologic aspects and damage to buildings, GRAĐEVINAR, 72 (2020) 10, pp. 843-867, doi: https://doi.org/10.14256/JCE.2966.2020

[2] Tower 8.1, Radimpex Software for Civil Engineers, 2020.

[3] Tehnički propis o izmjenama i dopunama Tehničkog propisa za građevinske konstrukcije - Prilog III. Razine obnove potresom oštećenih konstrukcija zgrada u odnosu na mehaničku otpornost i stabilnost (NN 75/20)

[4] Zakon o obnovi zgrada oštećenih potresom na području Grada Zagreba, Krapinsko-zagorske županije i Zagrebačke županije (NN 102/20),

[5] Prvi program mjera obnove zgrada oštećenih potresom na području Grada Zagreba, Krapinsko-zagorske županije i Zagrebačke županije (NN 119/20)

[6] 3Muri, S.T.A. DATA, Pushover and static analysis of masonry structures, 2018.

[7] Perić, L., Matorić, l.: Pouzdanost tradicionalnih zidanih građevina s drvenim stropovima na potresno djelovanje, GRAĐEVINAR, 72 (2020) 10, pp. 869-893, https://doi.org/10.14256/ JCE. 2965.2020
119/20). The aim was to demonstrate through this example how the seismic resistance of buildings can be restored and significantly increased in a short time through cooperation of all participants in the construction process, and through proper implementation of the above mentioned laws and regulations. The real test of expertise shown in the selection of renovation and strengthening methods, and in achievement of good quality in the realisation of works, was the earthquake that occurred on 29 December 2020 with the epicentre in the vicinity of Petrinja, during which the retrofitted building did not suffer any damage. It can therefore be stated that such an approach to the retrofit of damaged buildings, starting with rapid inspections and ending with the realisation of work, is the only correct approach to be strived toward by all participants in the process, so that the entire planned renovation can be completed as soon as possible, based on fully prepared documentation and involving good quality of works.

[8] Formisano, A.: Seismic behaviour and retrofitting of a school masonry building subject to the 2012 Emilia-Romagna earthquake, Italy, Naples, 2014, doi:10.4203/ccp.106.83

[9] Volken, N.: Evaluation of an existing masonry building with flexible diaphragms in Switzerland, Master thesis in structural engineering, Institute of structural engineering, Swiss Federal institute of technology in Zurich, Zurich, 2009.

[10] Sorić, Z.: Zidane konstrukcije, Zagreb, 2016. 544 str.

[11] HRN EN 1990:2011-Eurokod 0: Osnove projektiranja konstrukcija (EN 1990.2002+A1:2005+A1:2005/AC:2010); CEN: Brussels, Belgija, 2010.

[12] HRN EN 1998-3:2011/NA:2011-Eurokod 8: Projektiranje potresne otpornosti konstrukcija - 3.dio: Ocjenjivanje i obnova zgrada - Nacionalni dodatak); CEN: Zagreb, Hrvatska 2011.

[13] Mazziotti, A.: Structural analysis of historical masonry buildings, Ph.D Thesis, University of Naples Federico II, 2008.

[14] El Gawady, M., Lestuzzi, P., Badoux, M.: A review of conventional seismic retrofitting techniques for URM, $13^{\text {th }}$ International Brick and Block Masonry Conference, Amsterdam, 2004.

[15] Skejić, D., Lukačević, I., Ćurković, I., Čudina, l.: Application of steel in refurbishment of earthquake-prone buildings, GRAĐEVINAR, 72 (2020) 10, pp. 955-966, https://doi.org/10.14256/JCE.2970.2020 